\title{
Culture History of the Toalean of South Sulawesi, Indonesia
}

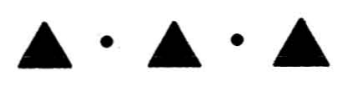

DAVID BULBECK, MONIQUE PASQUA, AND ADRIAN DI LELLO

THE TERM TOALEAN is here applied to microlithic assemblages in South Sulawesi (Fig. 1) with an age range between c. 8000 and 1500 B.P. They include a range of unifacially trimmed stone points, notably Maros points with bifacial, serrated retouch along the margins and a retouched hollowed base. Another group of microliths shows bidirectional blunting along their backs, resulting in backed blades in the case of elongated pieces, and geometric microliths when the artifacts are squatter in shape. Finely polished bone points and utilitarian shell artifacts are other common components (see Figs. 2 and 5).

Rock shelters with Toalean artifacts were first excavated in 1902 in the remote hinterland of Lamoncong (Sarasin and Sarasin 1905a). A resurgence of excavations in the late 1930s, which involved the Australian archaeologist Fred McCarthy, confronted archaeologists with the intriguing typological similarities between the Toalean and Australia's broadly contemporary "small tool tradition" (Bartstra 1998). The possibility of a prehistoric link between South Sulawesi and Australia inspired a second spate of excavations between 1969 and 1975, designed to date the Toalean radiometrically (Glover and Presland 1985; Mulvaney and Soejono $1970 a, 1970 b)$. Concurrently, Van Heekeren (1972) and Bellwood (1985) portrayed the Toalean as one of a multitude of microlithic or "flake-blade" industries in Island Southeast Asia. The question of an ancient relationship between South Sulawesi and Australia now tends to be held in abeyance (Mulvaney and Kamminga 1999:258).

As noted by Chapman (1986:83-84), considerable diversity can be observed within the Toalean. We shall interpret this phenomenon as an example of the general pattern of variety within Island Southeast Asian microlithic traditions. We shall also review the Toalean typological sequence based on the compilation and calibration of every available radiocarbon date, some of them unpublished. The dates will be expressed at the two-sigma confidence interval, using the CALIB 3.0 program, including the "model ocean marine mixed layer" correction (Stuiver et al. 1986) for samples of marine shellfish. Another goal is to synthesize the

David Bulbeck is a Postdoctoral Fellow at the School of Archaeology and Anthropology, Australian National University, Canberra; Monique Pasqua is the Senior Policy Officer of Aboriginal Heritage and Culture, Aboriginal Affairs Department, Perth, Australia; and Adrian Di Lello is a Ph.D. Scholar at the School of Archaeology and Anthropology, Australian National University, Canberra. 


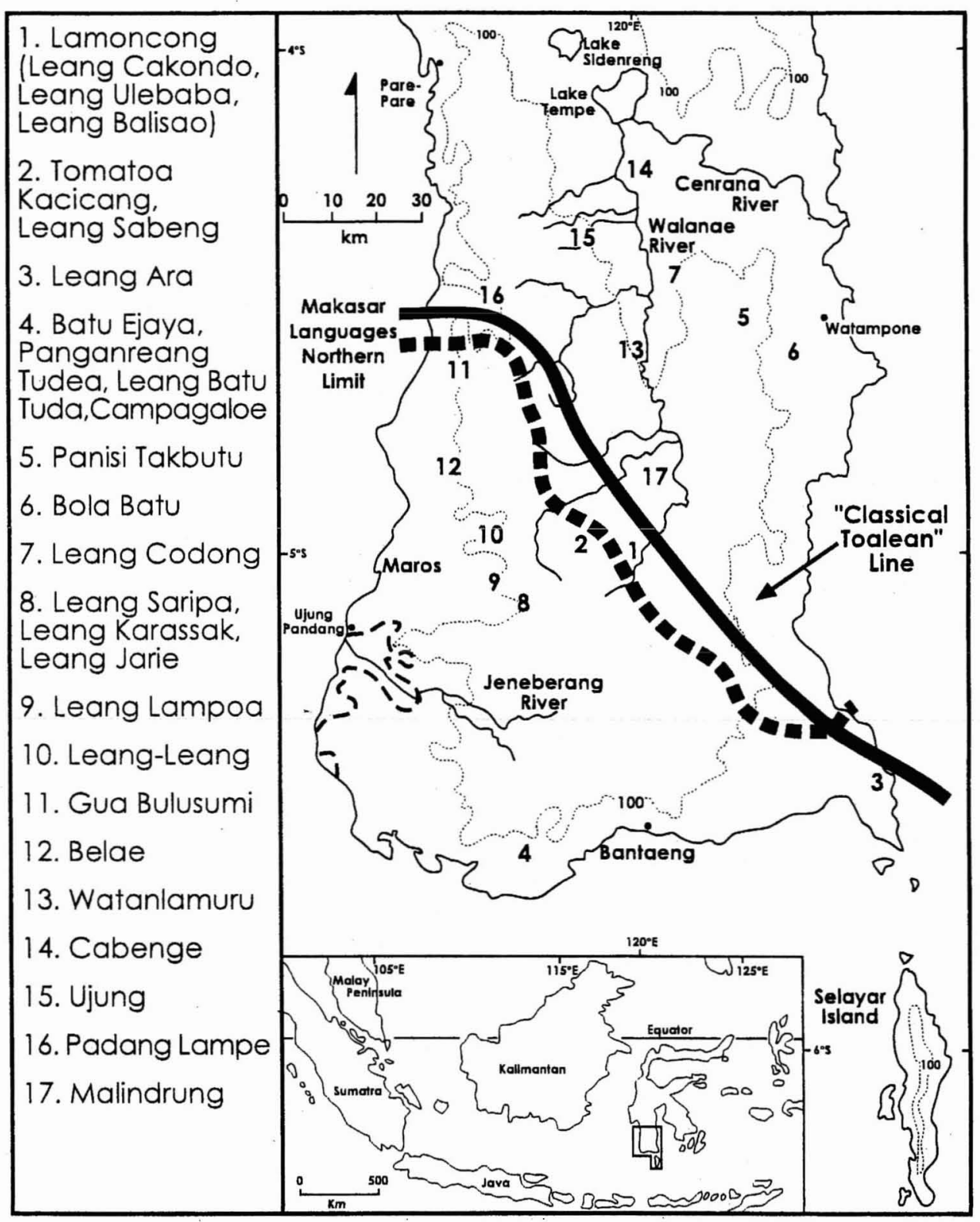

Fig. 1. South Sulawesi peninsula: main Holocene sites with flaked lithics and SSPHAP's Macassar survey (dashed).

available data from open Toalean sites, notably those recorded by Bulbeck (1992) during his South Sulawesi Prehistoric and Historical Archaeological Project (SSPHAP). The resulting landscape archaeology perspective will be linked to relevant geomorphological data: for instance, the evidence that the South Sulawesi peninsula was a virtual island during the middle Holocene (Gremmen 1990).

We are not interested in a typological culture history for its own sake but as a 
Table I. Summary of Contents from Toalean Rockshelters

\begin{tabular}{|c|c|c|c|c|c|c|c|}
\hline & $\begin{array}{l}\text { BACKED } \\
\text { BLADES }\end{array}$ & $\begin{array}{c}\text { GEO- } \\
\text { METRIC } \\
\text { MICRO- } \\
\text { LITHS }\end{array}$ & $\begin{array}{l}\text { MAROS } \\
\text { POINTS }\end{array}$ & $\begin{array}{c}\text { OTHER } \\
\text { STONE } \\
\text { POINTS }\end{array}$ & $\begin{array}{c}\text { BONE } \\
\text { POINTS }\end{array}$ & $\begin{array}{c}\text { POT } \\
\text { SHERDS }\end{array}$ & $\begin{array}{c}\text { METAL, } \\
\text { GLAZED } \\
\text { POTTERY, } \\
\text { GLASS }\end{array}$ \\
\hline \multicolumn{8}{|l|}{ Walanae headwaters } \\
\hline Leang Cakondo & - & —? & $x$ & $x$ & $x$ & $x$ & - \\
\hline Leang Ulebaba & - & —? & & & $\times$ & - & - \\
\hline Leang Balisao & - & - & - & - & - & $x$ & $x$ \\
\hline Tomatoa Kacicang & - & —? & $\times$ & $\times$ & $\times$ & $\times$ & $\times$ \\
\hline \multicolumn{8}{|l|}{ South coast } \\
\hline Leang Ara & $\times$ & $x$ & $x$ & $x$ & $x$ & $x$ & $\times$ \\
\hline Panganreang Tudea & $x$ & $x$ & $x$ & $x$ & $x$ & $x-$ & $x$ \\
\hline Batu Ejaya 1 & ? & $x$ & ? & $x \times$ & $x$ & $x \times$ & $x$ \\
\hline Batu Ejaya 2 & - & $x$ & - & $x$ & - & $x$ & $x$ \\
\hline Leang Batu Tuda & - & $x$ & & & & & \\
\hline \multicolumn{8}{|l|}{ Bone-Soppeng } \\
\hline Panisi Takbutu & - & - & - & $x$ & $x$ & - & - \\
\hline Bola Batu & - & —? & - & $x$ & $x$ & $x-$ & $x$ \\
\hline Leang Codong & - & - & - & $\times$ & $x$ & $x-$ & $x$ \\
\hline \multicolumn{8}{|l|}{ Patanuang Asue, Maros } \\
\hline Leang Saripa & -? & $x$ & $x \times$ & $x \times$ & $\times$ & $x$ & - \\
\hline Leang Karassak: & & & & & & & \\
\hline 1936 excavation & - & -? & $x$ ? & $x$ & - & $x$ & - \\
\hline 1969 excavation & - & $\times$ & $\times$ & $x$ & - & $x \times$ & $x$ \\
\hline Leang Lampoa & & & - & $\times$ & $x$ & $x \times$ & - \\
\hline Leang Jarie surface & - & - & $\times$ & $x$ & $\times$ & $x$ & $x$ \\
\hline \multicolumn{8}{|l|}{ Leang-Leang, Maros } \\
\hline Leang Pattae & $x$ & $x$ & $x$ & $\times$ & $x$ & $x-$ & - \\
\hline Leang Pette Kere & & & $x$ & & & $x$ & $x$ \\
\hline Leang Paja surface & —? & $x$ & $x$ & & & $x \times$ & $x$ \\
\hline \multicolumn{8}{|l|}{ Leang Burung 1: } \\
\hline Trench A spits $1-16$ & $x \times$ & $x \times$ & $x$ & $x \times$ & $x$ & $x \times$ & $x$ \\
\hline Tr. A spits $17-23$ & $x$ & - & $x$ & $x$ & $x$ & - & - \\
\hline Trench B & $\times$ & $x$ & $\times \times$ & $x$ & $x$ & $x-$ & - \\
\hline \multicolumn{8}{|l|}{ Ulu Leang 1: } \\
\hline spit 1 & $x$ & $x$ & $\times$ & $\times$ & $x$ & $x \times$ & $x$ \\
\hline spits $2-3$ & $x$ & $x$ & $x \times$ & $x$ & $x \times$ & $\times$ & - \\
\hline spits $4-11$ & $x \times$ & $\times$ & $x$ & $x$ & $x \times$ & 一 & - \\
\hline \multicolumn{8}{|l|}{ Pangkajene } \\
\hline Gua Bulusumi & & & $\times$ & $x$ & $x$ & $x$ & - \\
\hline Gua Macinai & & & - & & & $\times$ & \\
\hline Leang Garunggung & -? & -? & - & $x$ & - & $x$ & - \\
\hline Belae karsts (surface) & & & $x$ & $x$ & - & $x$ & $x$ \\
\hline
\end{tabular}

Note: $\times \times$ signifies abundant, $x$ signifies presence, $\times-$ signifies a slight presence of earthenware sherdage, - signifies absence, and blank spaces signify no evidence. Question marks indicate dubitable observations.

prerequisite to understanding the Toalean (Table 1). A thorough literature review is in order to improve the synthesis previously attempted by Van Heekeren (1972). The early excavations, even some by Van Heekeren, were of mixed quality and often scantly reported. The excavations by the 1969 Australian-Indonesian Expedition to South Sulawesi (Chapman 1981; Mulvaney and Soejono 1970a, 1970b), 
and by Ian Glover (1976, 1978), observed higher technical standards. Even here, however, we note problems like the consistent use of arbitrary spits to excavate sites with a complex stratigraphy. We shall follow the excavations in approximate chronological sequence, as ideas on Toalean classification changed with time. For instance, the earliest references to hafted microliths postdate McCarthy's visit to South Sulawesi in 1937, and the first unambiguous reference to backed implements in a specific site dates to 1952 (by Van Heekeren). Similarly, the term Maros point was coined only in 1970 (Mulvaney and Soejono 1970a, 1970b).

The very use of the term Toalean, from the Bugis word Toale' or "forest people," is problematical. The Sarasins named the excavated assemblages after the Toale' who occupied certain rock shelters in Lamoncong, even though these people used metal tools, had no knowledge of flaking stone, and grew rice and maize (Sarasin and Sarasin 1905b:16, 272, 286). Fritz Sarasin (1906:150-155) claimed that the wavy hair and body measurements of the "Toalas" distinguished them from other Sulawesi people, but he invalidated his study by using physical appearance as his criterion to choose Toala subjects from five separate places across Sulawesi. When Van Stein Callenfels later measured a sample of Lamoncong Toale', selected solely on the basis of lacking any recognized ancestry with the Bugis around them, these Toale' and Bugis did not evince any discernible anthropometric differences (Mijsberg 1941). Further, Pelras (1996:37) reports historical evidence that the Toale' were Bugis exiles, socially but not ethnically distinct from their Bugis neighbors. If there had once been a linguistic distinction, it did not emerge during the comprehensive survey of South Sulawesi languages undertaken by the Summer Institute of Linguistics (Grimes and Grimes 1987).

The debate on the ancestry of the Toale', and what might have happened to the Toaleans, calls up Bellwood's (1997) use of the appearance of pottery to mark the colonization of Island Southeast Asia by Austronesian-speaking farmers. Earthenware sherds occur in late Toalean sites, raising the question of whether Toaleans ever spoke an Austronesian tongue. Further, as we shall demonstrate, the main facies (if we may use that term) of the Toalean corresponds closely to the area where the Makasar languages (Austronesian) are spoken today. This observation will be interpreted as evidence of close interaction between farmers and huntergatherers in late prehistoric South Sulawesi.

\section{EXCAVATIONS IN THE WALANAE HEADWATERS}

The main site excavated by the Sarasins in Lamoncong was the upper chamber of Leang Cakondo (Fig. 1). Sherds indistinguishable from modern pots made by the local Bugis were found mainly near the surface. The densest assemblage, between 10 and $40 \mathrm{~cm}$ in depth, contained projectile points and other flake tools with retouched serrated edges, plus bladelets and bone points. Some of the serrated projectile points have the hollowed base characteristic of Maros points (Sarasin and Sarasin 1905b:282-284; Van Heekeren 1972:108). In the lower Cakondo chamber, the Sarasins recovered a similar assemblage of microliths and bone points (Sarasin and Sarasin 1905a:6; Van Heekeren 1972:108). Leang Ulebaba produced a sparser assemblage that lacked pottery, although some very fine bone points are mentioned (Sarasin and Sarasin 1905b:188). Leang Balisao, the last excavated shelter, contained Chinese and European ceramic sherds and fragments 
of iron, but few other artifacts (Sarasin and Sarasin 1905a:22-23, 1905b:292293). It arguably represents Toale' rather than Toalean material culture (Table 1).

Sarasin and Sarasin (1905a, tables I-III) illustrate scraper-like forms and a bone bladelet with serrations, as well as serrated points. Van Heekeren (1972:106) specifies geometric microliths in his general description of the Sarasins' excavations, but we do not know on which evidence. The Sarasins (1905a, 1905b) did not describe or depict any backed implements, though this deficiency might reflect their lack of awareness of backing as a technique of formal retouch.

In 1933 Van Stein Callenfels, Noone, and Cense revisited Lamoncong and excavated Leang Sebang, which is totally unreported, and Leang Tomatoa Kacicang. The latter site produced the bladelets, serrated projectile points, bone points (sometimes with serrated edges), and earthenware sherds as previously reported by the Sarasins. It also yielded a polished stone adze, a stone barkcloth beaker, a fragmentary iron spear, and two fragments of green glass bracelets reportedly excavated in the lowest level. The last finds particularly suggest that the whole assemblage may date to the last two millennia (Van der Hoop 1941:280, 306; Van Heekeren 1972:109; Van Stein Callenfels 1938a). To summarize the reported data from Lamoncong, there would seem to have been an emphasis on serrated artifacts of bone as well as stone, and this specialization evidently lasted into the Metal phase. Backed implements are absent or rare, consistent with the technological emphasis on serration.

\section{THE SOUTH COAST EXCAVATIONS}

In 1936 Van Heekeren excavated 36 miniature points, which he interpreted as fishing spearheads, and seven larger points at Leang Ara, on the southeast tip of the peninsula. Two of the small points (one serrated and one unserrated) had hollowed bases, while most of the other small points reportedly had serrated margins. Sometimes, however, these were blunt serrations cut perpendicularly into the long axis of the point, and three of the points were worked only along one margin (Van Heekeren 1937). In a later account of the same implements, Van Heekeren $(1949: 91,101)$ described the blunt invaginations as having been worked sideways, or horizontally, and towards the ventral surface as well. These observations appear to describe microliths with bidirectional backing along one margin, even though Van Heekeren (1972:110) never advanced this identification. Photographs of the specimens (Van Heekeren 1937) show that Nos. 9 and 15 could be classified as backed blades, and No. 16 as a geometric microlith. Other finds included circa fifteenth-century East Asian ceramic sherds (Jakarta National Museum Accession No. 3491), a bead of light blue glass, bone points, and a concentration of earthenware sherds near the surface (Van Heekeren 1937, 1972:110).

The 1937 excavations in Batu Ejaya 1 and Panganreang Tudea, by Van Stein Callenfels, are so poorly documented that often it is not clear what was found where. Apparently he kept all the bone, metal, and polished stone that he noticed, and much of the flaked stone, but left most of the pottery. Most but not all of the faunal remains were still provenanced by site when they were sent to Dammerman (1939) for identification (see also Hooijer 1950). Van Stein Callenfels deposited the artifacts he had collected in the Prehistory Collection at 
Table 2. Comparison of Reported Artifact Frequencies From the I937 South Coast Excavations

JAKARTA'S NATIONAL MUSEUM HOLDINGS FOR

“PANGANREANG TUDEA" (CHAPMAN 1981)
BATU EJAYA (BOLD) + PANGANREANG TUDEA ACCORDING TO VAN HEEKEREN (1949)

$55 \times 4= \pm 220$ backed microliths

$47 \times 4= \pm 188$ points with serrated edges

Sum: \pm 408 implements with "barbed" edges

$70 \times 4= \pm 280$ points lacking serrated edges

About 100 bone implements

4 pot sherds

$$
\begin{aligned}
& \mathbf{5 3}+143=196 \text { barbed implements } \\
& \mathbf{1 4 0}+88=228 \text { stone knives } \\
& \mathbf{1 1}+\mathbf{5 5}=66 \text { bone implements } \\
& \mathbf{0}+13=13 \text { pot sherds }
\end{aligned}
$$

Note: 7 of the 117 points examined by Chapman (1981:139) had shallow hollowed bases and would be classified as Maros points except when the definition of this tool type requires the depth of the hollow to exceed $2 \mathrm{~mm}$.

Batavia, now Jakarta's National Museum. They are registered under Accession Nos. 3530-3564 in Van der Hoop's 1941 catalogue, all attributed to the excavation at Panganreang Tudea by Van Stein Callenfels and Willems. This registration is confusing, as we learned from other documentation. At least some of the items are from Batu Ejaya, for instance, the coins (Van Stein Callenfels 1938a:582) under Accession No. 3551, and the stone beater (Van Heekeren 1949:94) under No. 3564. Moreover, Willems did not attend the south coast excavations. Evidently, Van der Hoop catalogued the deposited items from both sites under Panganreang Tudea, which has led to the impression that the Batu Ejaya items have been lost (Chapman 1981 :113; Mulvaney and Soejono 1970a:28).

Shortly after World War II, Van Heekeren (1949:93-94) discovered lists of the main finds from both sites. Later he relocated Van Stein Callenfels' field notes and maps of Panganreang Tudea, and was able to relate them to the museum collection through undisclosed means (Van Heekeren 1957:92, 1972:113). The members of the 1969 Australian-Indonesian Expedition to South Sulawesi could not locate the records that Van Heekeren mentioned on the c. 6000 artifacts accessioned under Panganreang Tudea at Jakarta's National Museum (Mulvaney and Soejono 1970b:168-169). Chapman (1981:133-139) provides some figures on the collection. These match quite well against the frequencies of the comparable artifact classes as had been reported by Van Heekeren (1949:93-94) for Batu Ejaya plus Panganreang Tudea (Table 2). Chapman's and Van Heekeren's sets of frequencies are brought towards compatibility only by assuming (as indicated on other grounds) that the Panganreang Tudea collection at the National Museum includes many artifacts from Batu Ejaya.

Van Heekeren's access to original records from the excavation privileges his interpretation of Panganreang Tudea. Further, Glover (1976) obtained a highly congruent sequence at Ulu Leang 1, supporting the validity of the cultural layers identified by Van Heekeren and, indeed, suggesting their approximate age. Van Heekeren recognized a lower layer at Panganreang Tudea, which lacked microliths. It is comparable to the four basal spits in the 1969 excavation at Ulu Leang 1 (Glover 1976, table 2), and so is probably of initial Holocene age. Van Heekeren recognized a middle Panganreang Tudea layer containing arrowheads with rounded bases, backed blades, and abundant geometric microliths. Backed micro- 
liths are particularly well represented in the early-middle Holocene levels at Ulu Leang 1 (see below). The upper Toalean layer at Panganreang Tudea, according to Van Heekeren (1972:113), was "characterized by barbed stone arrowheads, many of them winged at the base, ... bone points, shell scrapers and some potsherds." Late Holocene finds in this layer extend to a bronze fishhook and a stone bead (Van Heekeren 1972:113), as well as supine inhumations dug into the sediments (Bulbeck 1996-97:1028; Van Stein Callenfels 1938a:583). As our review of the Maros sites will indicate, the upper layer at Panganreang Tudea would have included middle to late Holocene items commingled through disturbance and conflation.

At Batu Ejaya 1, Van Stein Callenfels (1938a:582) encountered a compact layer, between 18 and $40 \mathrm{~cm}$ in depth, thick with decorated potsherds. It also contained bone points, flaked stone, a few polished adzes, and two bronze bracelet fragments. Van Heekeren (1949:93-94) added a stone bracelet, a stone barkcloth beater, and shell artifacts to the recorded repertoire, plus the information that 53 of the stone tools were serrated. When Mulvaney and Soejono (1970a: 30-31; Chapman 1981) re-excavated the site, they struck a pale clay layer, which they recognized as Callenfels' refill, replete with the decorated pottery and other artifacts he had reburied. In 1997, Bulbeck obtained radiocarbon dates on samples of marine shell from square 1 spit 5 (the pale clay) and square 2 spit 1 (at the intersection of the pale clay with the overlying black soil). These samples produced the dates of 4420-4780 B.P. and 4320-4705 в.P., respectively (Table 3), demonstrating occupation of this hinterland rock shelter by at least 4400 B.P.

Mulvaney and Soejono also excavated a unit of red-brown clay, which stratigraphically underlay Van Stein Callenfels' refill outside the shelter's overhang. This layer produced most of the assemblage characterized by Chapman (1981, 1986) as including numerous miscellaneous stone points (some with serrated edges), but no bone points, Maros points, or backed microliths. Charcoal from this layer, sealed beneath a semicomplete pot, was dated 340-1340 B.P. (Table 3). Given this date, the lack of "classic" Toalean types, the stone bracelet fragment recovered by Mulvaney and Soejono (1970b:167), the bronze and polished stone dug up by Van Stein Callenfels, and the abundance of pottery reaching to almost the same depths as the lithics, Chapman concluded that Batu Ejaya 1 represented a very late phase of the Toalean. The mid-Holocene dates now available on marine shell would not necessarily contradict Chapman's view. Marine shell is scarce in the red-brown clay. Hence this unit could arguably have been deposited c. 1000 B.P., subsequent to earlier, sporadic occupation beneath the overhang as represented by the dates on shell (Simons 1997:130-131).

On the other hand, the decorated pottery had evidently been buried into the deposits. It could well have been associated with human cremations, as would explain the large charcoal sample sealed in a pot, and the lack of identified human remains apart from four loose teeth (see Flavel 1997:49; Hooijer 1950:68). In that case the c. 1000 B.P. determination would date the pottery rather than the lithics. The evident confusion of Batu Ejaya and Panganreang Tudea artifacts in Jakarta's National Museum collection implies that at least some classic Toalean types may have been collected by Callenfels at Batu Ejaya. Moreover, Mulvaney and Soejono (1970b:167) reported a bidirectionally backed geometric microlith from their excavation, even though it appears to have been misplaced before the 
Table 3. Radiocarbon Dates From Toalean Sites

\begin{tabular}{|c|c|c|c|c|}
\hline SITE & LAB. NO. & MATERIAL & DETERMINATION & $\begin{array}{c}\text { CALIBRATED } \\
\text { 2-SIGMA RANGE }\end{array}$ \\
\hline Batu Ejaya 1 & ANU-392 & Charcoal & $920 \pm 275$ в.Р. & 340-1340 в.P. \\
\hline Batu Ejaya 1 & Wk-5464 & Marine shell & $4430 \pm 50$ в.Р. & $4420-4780$ в.P. \\
\hline Batu Ejaya 1 & Wk-5465 & Marine shell & $4370 \pm 70$ в.Р. & 4320-4705 в.P. \\
\hline Leang Karassak & Wk-3824 & Charcoal & $370 \pm 50$ в.P. & 300-510 в.Р. \\
\hline Leang Karassak & Wk-3823 & Charcoal & $2690 \pm 60$ в.P. & $2740-2880$ в.P. \\
\hline Leang Burung 1B & ANU-390 & Charcoal & $3420 \pm 400$ в.P. & $2750-4830$ в.P. \\
\hline Leang Burung 1B & ANU-1264 & Charcoal & $4880 \pm 480$ в.P. & $4360-6670$ в.P. \\
\hline Leang Burung 1B & ANU-6175 & Apatite & $4610 \pm 220$ в.P. & 4650-5855 в.P. \\
\hline Leang Burung 1A & ANU-391 & Charcoal & $2820 \pm 210$ в.P. & 2360-3460 в.P. \\
\hline Leang Burung 1A & ANU-6172 & Collagen & $1160 \pm 200$ в.P. & 670-1410 в.р. \\
\hline Leang Burung 1A & ANU-6173 & Apatite & $1660 \pm 190$ в.P. & 1180-1990 в.P. \\
\hline Leang Burung 1A & ANU-6173 & Collagen & $2260 \pm 90$ в.P. & 2010-2460 в.P. \\
\hline Leang Burung 1A & ANU-6174 & Apatite & $640 \pm 240$ в.P. & 0-1050 в.Р. \\
\hline Leang Burung 1A & ANU-6174 & Collagen & $1660 \pm 190$ в.P. & 1180-1990 в.P. \\
\hline Ulu Leang 1 & PRI-230 & Charcoal & $3550 \pm 130$ в.P. & 3470-4220 в.P. \\
\hline Ulu Leang 1 & HAR-1734 & Charcoal & $4050 \pm 90$ в.P. & 4280-4830 в.P. \\
\hline Ulu Leang 1 & PRL-231 & Charcoal & $4390 \pm 110$ в.Р. & 4650-5310 в.P. \\
\hline Ulu Leang 1 & GRN-8647 & Fresh shell & $8895 \pm 50$ в.P. & 8000-8420 в.P. \\
\hline Ulu Leang 1 & ANU-394 & Charcoal & $5740 \pm 230$ в.P. & $6000-7160$ в.P. \\
\hline Ulu Leang 1 & SUA-1080 & Charcoal & $1490 \pm 210$ в.P. & 960-1860 в.P. \\
\hline Ulu Leang 1 & GRN-8291 & Fresh shell & $8785 \pm 45$ в.P. & 7950-8360 в.P. \\
\hline Ulu Leang 1 & GRN-8290 & Fresh shell & $10,560 \pm 50$ в.P. & $9940-10,370$ в.P. \\
\hline Ulu Leang 1 & GRN-8648 & Fresh shell & $10,740 \pm 50$ в.Р. & $10,040-10,800$ в.P. \\
\hline Ulu Leang 1 & ANU-606 & Charcoal & $7170 \pm 650$ в.P. & 6720-9450 в.P. \\
\hline
\end{tabular}

Notes: In both cases where the apatite and collagen fractions were dated from the same samples of human bone at Leang Burung 1, Trench A (ANU-6173, ANU-6174), they almost overlap at two-sigma. These bone samples most likely date to c. 2000 B.P. and 1000 B.P. respectively.

Following the recommendation of Bronson and Glover (1984:40), the Ulu Leang 1 dates on freshwater shell in Table 2 and Figure 3 have had 1300-1500 years subtracted from them prior to calibration.

lithics could be examined by Chapman (1981) or Di Lello (1997:26). The probably small complement of formal Toalean tools from Batu Ejaya 1, including the bone points reported by Callenfels (Table 1), would appear to refer to the site's middle Holocene occupation, even if the main period of use of the shelter may have been late Holocene.

At Batu Ejaya 2, a small shelter adjacent to Batu Ejaya 1, Mulvaney and Soejono (1970a:31; Chapman 1981) excavated ten geometric microliths, various miscellaneous points, and pottery. The shallow sediments also yielded historical artifacts at all depths, and the charcoal date from the base of the deposit was modern. Excavation of another nearby shelter, Leang Batu Tuda, produced a number of geometric microliths (Mulvaney and Soejono 1970b:168), as personally observed by Bulbeck.

In summary, the Toalean sites along the peninsula's south coast include one site (Panganreang Tudea) whose sequence apparently spanned much of the Holocene, and a second site (Batu Ejaya 1) with a middle to late Holocene sequence. Thus, gaps in the chronology could not be reasonably proposed as an explanation for the distinctive features of the south coast assemblages. One such feature is the 
scarcity of Maros points, and the shallowness of their hollowed bases, compared to the Lamoncong sites. Serrated points occur frequently but mainly in combination with untrimmed bases. Backed blades and geometric microliths, neither of which were clearly present at Lamoncong, are also common, and at least one of these types is present at every excavated site. Finer understanding of the Toalean along the south coast is prevented by Van Stein Callenfels' abysmal archaeological standards, the registration of many of the Batu Ejaya artifacts under Panganreang Tudea, and the high levels of post-depositional disturbance plaguing at least some of the sites.

\section{Bone and Soppeng}

The other contribution by Van Stein Callenfels was his 1937 excavation of Panisi Takbutu in Bone, on the eastern slopes of the peninsula. He was accompanied by the Dutch archaeologist Willems, and McCarthy from Australia. No mention is made anywhere of potsherds or other late Holocene artifacts. As reported, the assemblage included stone blades and knives, 16 points and other stone artifacts with serrations, bone points and spatulas, and scrapers of stone and shell (Van Stein Callenfels 1938b; Van Heekeren 1972:112). Maros points were apparently absent, as hollowed bases are not mentioned on any of the stone points; indeed, any retouch here would seem to have been restricted to producing peduncles (see also Van Stein Callenfels 1938a:581). Nor would any of the serrated artifacts appear to have been backed microliths, given that McCarthy $(1940: 38-39)$ did not claim the existence of any geometric microliths in South Sulawesi, and nominated "Batavia Museum specimens" (i.e., artifacts excavated before 1937) as examples of Toalean backed blades.

True, Van Stein Callenfels (1938b:140-141) suggested that the unilateral serrations found on some of the Panisi Takbutu artifacts could have allowed them to be fastened in slots prepared in wooden handles, but he also stressed the bilateral occurrence of similar serrations on other specimens, incompatible with backing. In his view, only two of the hundreds of stone tools excavated in all of South Sulawesi's rock shelters could be considered geometric microliths. Actually he appears to have been unable to recognize geometric microliths, as he completely overlooked the numerous examples he later excavated at Panganreang Tudea (Van Heekeren 1957:92, 1972:113). However, had there been backed microliths at Panisi Takbutu, McCarthy should have alerted Callenfels to their presence. McCarthy was probably the inspiration for Callenfels' idea that the Panisi Takbutu microliths with unilateral serrations could have been inserted into handle slots. Hafted or not, asymmetric points with serrations along only one margin are sometimes illustrated from Toalean assemblages (e.g., Chapman 1981, fig. 7.9q; Sarasin and Sarasin 1905a, fig. 27; Van Heekeren 1972, pl. 91, No. 3608).

An assemblage very comparable to Panisi Takbutu's was recovered from Bola Batu, the other excavated rockshelter in Bone, and the best reported of the Dutch excavations (Van Heekeren 1949). Fourteen glazed sherds and eight earthenware sherds were excavated, but they were clearly intrusive as indicated by their concentration in the top $20 \mathrm{~cm}$, and the equally deep penetration of the glazed and earthenware sherds in the deposit. Various unprovenanced fragments of iron, and a polished axe fragment from an upper level, may well be intrusive, too. Van 
Heekeren also excavated a partial human skull at a depth above the deepest sherds; however, Hooijer (1950:61) describes it as fossilized, which would suggest that it had been buried millennia ago. In all, the most plausible interpretation of Bola Batu would entertain two phases: a late use, which may have been restricted to the second millennium A.D., and an earlier Toalean occupation, which was essentially or entirely preceramic.

This assemblage is characterized by shell scrapers and a wide range of points, of which the "muduk" bone points and round-based, unserrated "pirri" stone points were explicitly classified in the Australian terminology. Van Heekeren specified that the small number of serrated stone points all lacked a hollowed base. He further identified asymmetric triangular points designed to be hafted in a series, but made no reference to backing or geometric microliths (Van Heekeren 1949:103). Even after 1952, when we know Van Heekeren could recognize backed microliths, he did not claim their presence at Bola Batu. His later summaries merely mention "types of a semi-microlithic character" (Van Heekeren 1957:94) and "types of a geometric-microlithic character" (Van Heekeren 1972:114). To judge from the illustrated asymmetric triangular points at Bola Batu, such as artifacts 388 and 427 (Van Heekeren 1949:98), serration was the retouching technique that might have allowed these points to be hafted.

Along the Walanae River in Soppeng lies Leang Codong, whose deposit was totally removed by Willems and McCarthy in 1937 (Bulbeck 1992:445-446). They recovered human remains at all depths (Van Stein Callenfels 1938b:139), especially the 2500 teeth whose size and morphology align them with modern Indonesians (Bulbeck 2000a; Jacob 1967). Fred McCarthy (pers. comm. 9 Feb. 1985) kept a diary of the main finds from the excavation and these include serrated stone tools, an arrowhead, shell scrapers, shell and bone points, 15 beads including 1 of white stone and 2 of red carnelian, and an iron spearhead from the deepest level of the deposit. McCarthy's records accord with the National Museum's registered holdings: a denticulated stone arrowhead, 61 shell artifacts, 7 sea urchin spines, an iron point, and bronze leaf (Accession Nos. 5529, 55515554, 5586). In addition, after World War II Van Heekeren (1949:93) found some labeled finds from Leang Codong in the Batavia Office of the Archaeological Survey, as well as Willems' plan and photographs of the site. These presumably formed the basis for Van Heekeren's (1957:91, 1972:112) summary of pot sherds, a few metal objects, shell scrapers, and 12 barbed stone implements. No accounts mention hollowed bases on the stone point(s).

All accounts agree that the deposits were unstratified. The simplest interpretation of Leang Codong is that the human remains were buried with the metals, beads, and possibly some pots, and this mortuary use of Leang Codong thoroughly disturbed the previous Toalean habitation debris, which may have been preceramic. The Toalean tools would have consisted of at least one stone point, bone points, and a wide range of shell artifacts (as also recorded at Panisi Takbutu and Bola Batu). Here we may infer that backed implements had not been exhumed, as otherwise McCarthy could be expected to have observed them.

The excavated Toalean assemblages from the eastern and central peninsula share a number of features that distinguish them from other Toalean assemblages. They lack Maros points and have very few if any backed implements, whereas bone and shell were widely utilized. Van Heekeren $(1949: 101)$ mentioned that 
the Bola Batu stone artifacts were made from an inferior type of volcanic stone, but there is no evidence to suggest that fine cryptocrystalline stone was not utilized at Panisi Takbutu or Leang Codong.

\section{THE PATANUANG ASUE VALLEY SITES, MAROS}

In 1936 and 1937, Van Heekeren excavated two shelters facing each other across the Patanuang Asue River, which drains the limestone karsts behind the Maros coastal plain. Although only his description of one of these shelters, Leang Saripa, is at all complete, Leang Karassak was test-pitted again in 1969 during the Australian-Indonesian Archaeological Expedition to South Sulawesi.

Leang Saripa proved to be a prolific Toalean site. There was a large number of projectile points, approximately 80 percent of them with hollowed bases, and approximately half of these had serrated edges. Other formal types included bone points and a few geometric microliths, and a wide range of borers, awls, tanged points, and points denticulated along one margin, although no backed blades are depicted or described. There were reportedly few pot sherds, all of them restricted to the uppermost levels, no human remains and no metal (Van Heekeren 1939, 1972:111-112, pl. 91; Van der Hoop 1941:177-178). This may be the least disturbed Toalean site ever excavated. Glover $(1978: 69)$ reported that the deposit had been totally removed.

Information on the 1936 excavation of Leang Karassak is limited to fleeting descriptions by Van Heekeren (1937, 1949, 1957:89-90, 1972:110-111), and Van der Hoop's (1941) catalogue of the finds. The deposits reportedly consisted of a loose upper layer with pot sherds, and a lower shelly layer with the majority of the stone artifacts. These included denticulated and undenticulated projectile points; although Van Heekeren $(1972: 111)$ protested that none had a hollowed base, No. 3409 has serrated edges and a slight concavity at its base (Van Heekeren 1972, pl. 91), while No. 3411 was registered as a denticulated winged arrowhead (Van der Hoop 1941:175). There is no mention of backing although No. 3424 was registered as a geometric knife (Van der Hoop 1941:176). Bone tools were scarce and bone points are not specified (Van Heekeren 1972:111). A blue glass bead supposedly handed over by Van Heekeren from the site (Van der Hoop 1941 : 271) must actually be the Leang Ara bead, as Van Heekeren (who excavated Leang Karassak and Leang Ara during the same season) never himself referred to any beads from Leang Karassak.

Campbell Macknight's 1969 test pit encountered an overlying brown sediment evidently redeposited through disturbance post-dating Van Heekeren's excavation (Pasqua 1995; Pasqua and Bulbeck 1998). It contained abundant lithics including the basal portion of a Maros point. Beneath this redeposited layer was a black, greasy layer radiocarbon dated A.D. 1440-1650, in which seventeenth- to nineteenth-century Chinese sherds occurred. Fragments of iron continued down to the top of the next layer, a brown clayey sediment, which also yielded a geometric microlith. Potsherds were common down to the base of the brown clayey sediment which, at about $90 \mathrm{~cm}$ in depth, overlay a mounded midden corresponding to the shelly, preceramic layer recorded by Van Heekeren. The junction of the clayey sediment and the shelly deposit is dated to 2740-2880 B.P. (Table 3). A second geometric microlith was found immediately underneath. No bone 
tools or polished stone appeared at all, but miscellaneous stone points with sparse or no serrations were common. Combining the evidence from Macknight's and Van Heekeren's excavations, we infer that the ceramic Toalean at Leang Karassak, associated with geometric microliths, may have begun at around 3000 B.P. Serrated points would appear to have been restricted to older levels, and it is from there that the redeposited butt of a Maros point presumably originated.

In 1948 Franssen (1949) excavated Leang Lampoa near the junction of the Patanuang Asue and Leang-Leang rivers. The excavated assemblage (Accession Nos. 5744-5754 in Jakarta's National Museum) included stone points-none of them barbed or possessing hollowed bases-shell scrapers, some bone points, and abundant pot sherds in the upper layer. The status of any backed microliths cannot be guessed from Franssen's account. Nor did he discuss how the obsidian flake from Leang Lampoa, and the copious quantities of freshwater shell, related stratigraphically to the pottery. A rather modern-looking human burial was also exhumed (Hooijer 1950). Too few details have been provided on Leang Lampoa to fathom its relationships with other, better documented sites in the Maros region.

Finally, the 1969 Australian-Indonesian Archaeological Expedition made a surface collection at Leang Jarie (Mulvaney and Soejono 1970a:175). Bulbeck recorded earthenwares and glazed ceramics, bone points, worked shell (points and scrapers), a "pirri" point and a Maros point in the collection (Fig. 2). Bartstra (1998, pl. 6) illustrates another "muduk" bone point from the site.

\section{LEANG-LEANG, MAROS}

Leang-Leang contains the main concentration of known Toalean sites, even though excavations did not start here until after World War II. In 1950 Van Heekeren (1952) excavated Leang Pattae and recovered essentially the same sequence that subsequent excavations at Leang Burung 1 and Ulu Leang 1 revealed (see below). Potsherds were restricted to the uppermost deposit, while serrated and/or hollow-based projectile points were found throughout the upper layer. The other stone tools, which Van Heekeren presumably extracted from the lower as well as the upper layer, reportedly included blades and bladelets, stemmed and round-based points, scrapers, and geometric microliths. Some of the latter would more properly be classified as backed blades from their description as "batteredback blade-points" (Van Heekeren 1972:116-118). The superficial position of the pottery suggests that much or all of this Toalean sequence was aceramic, including its later stage when Maros points were added to the production of backed microliths. Four shell scrapers and a single bone point were also unearthed.

Two minor projects can be noted before we move on to the main Toalean sites at Leang-Leang. In 1970, the Indonesian archaeologist Hadimuljono excavated Leang Pette Kere, as reported by a sign for visitors at the entrance to the LeangLeang Archaeological Park. The sign mentions stone flakes, a Maros point, molluscan and other food remains, pottery, a polished stone axe and glass beads. Second, Ian Glover (1978:71-72) collected backed blades (possibly including geometric microliths) and Maros points from the highly disturbed surface of Leang Paja. He also retrieved a polished stone axe, and highly ornate earthen pottery very similar to the c. 3000-year-old pottery from the Kalumpang sites in Central Sulawesi (see Bulbeck 2000b; Flavel 1997). The Leang Paja pottery may 

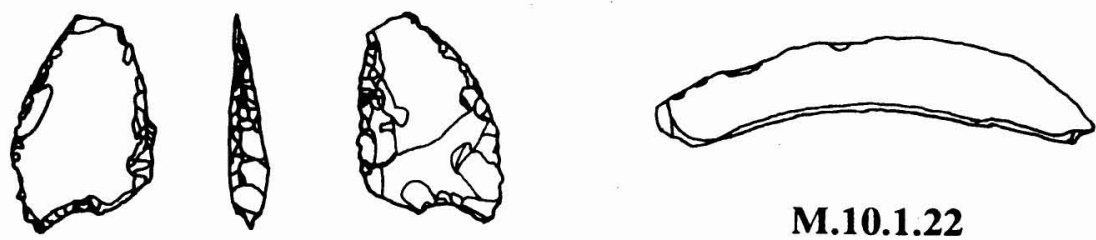

M.10.1.22

M.10.1.5
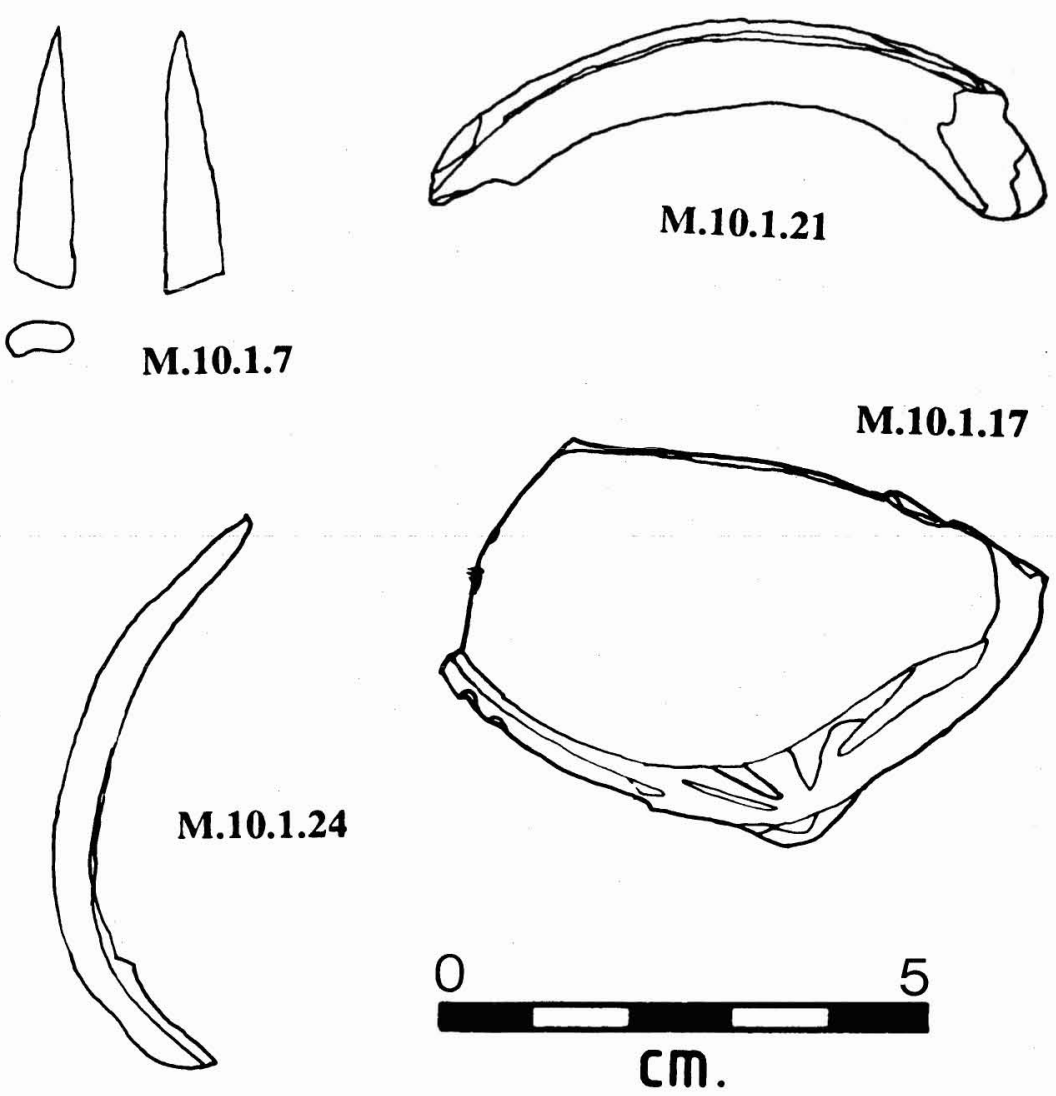

Fig. 2. Implements from the Leang Jarie surface collection. M.10.1.5: Maros point with broken tip. M.10.1.7: Bone point. M.10.1.24: Shell hook from bivalve rim. M.10.1.22: Shell point from bivalve rim. M.10.1.21: Shell scraper from bivalve rim. M.10.1.17: Shell scraper from cockle.

be Neolithic rather than Iron Age as no metals have been reported from the site, and its few Chinese sherds probably derived from the looted burial ground directly below the cave.

\section{Leang Burung 1}

Leang Burung 1 hosted the major excavation by the Australian-Indonesian Archaeological Expedition to South Sulawesi (Mulvaney and Soejono 1970a). 
Three layers are recognized: a white rubbly layer, restricted to the interior of the shelter; beneath it, a gray zone laced with shelly lenses; and a brown sand that constituted the basal deposit of Trench A inside the shelter, and about half of the excavated deposits of Trench B outside of the shelter. The single charcoal date from Trench A (near the base of the gray zone) dates to 2360-3460 B.P., and the two-sigma ranges of the three radiocarbon dates from the brown sand in Trench B all overlap at 4650-4830 B.P. (Table 3). Hence, the transition from the brown sand to the overlying gray zone would date between 3500 and 4500 B.P. The site was excavated in approximately $10-\mathrm{cm}$-deep spits, which often dissect the complexly shaped stratigraphic layers. The resulting uncertainty in the exact stratigraphic provenance of certain excavated materials has had to be accommodated in the site's interpretation (Pasqua 1995; Pasqua and Bulbeck 1998).

Most of the Toalean lithics from Trench B lay near the junction of the gray and brown zones, above the radiocarbon-dated materials (Pasqua and Bulbeck 1998). This observation suggests a maximum age of around 4700 B.P., while the near absence of pottery, restricted to eight sherds, suggests a minimum age of around 3500 B.P. (see below). The formal tools are dominated by points, including 24 Maros points, 24 other stone points, and 19 bone points. Backed implements, namely 7 backed blades and a geometric microlith, are less common (Chapman 1986:78, 81). Similar proportions of the same artifact types were recorded in spits 17-23 in Trench A, beneath that trench's 2360-3460 B.P. charcoal date: no pottery, six Maros points, two other stone points, less than seven bone points, and two backed blades (cf. Chapman 1981:50A, 103A). Both preceramic Toalean assemblages, with their prominence of Maros and other stone points, would appear to correspond to Van Heekeren's assemblage at Leang Pattae immediately beneath the earthenware sherds.

Spits 1-16 in Trench A, above the 2360-3460 B.P. date, contained a ceramic Toalean assemblage with 963 pot sherds, 57 miscellaneous stone points, 51 backed blades, 52 geometric microliths, but only 7 Maros points and no more than 7 bone points (cf. Chapman 1981:50A, 103A; 1986:78, 81). Thus, production of Maros points seems to have dwindled at Leang Burung 1 after the introduction of pottery, even though the manufacture of other stone points and backed implements persisted, as in the ceramic layers at Leang Karassak. Another similarity between the ceramic Toalean assemblages at Leang Burung 1 and Leang Karassak is the lack of evidence for shell artifacts, in contrast to the utilized bivalve fragments recovered from Trench B at Leang Burung 1 (Simons 1997: 76, $86,103)$.

Spits 1-16 in Trench A also yielded abundant fragments of human bone from secondary burials. The burials were probably not associated with the trench's plain pottery, whose classification as cooking vessels and other utilitarian wares (Chapman 1981:109) would make them unlikely grave goods. However, the burials may well be associated with the piece of corroded iron and the few decorated sherds in the trench, as well as the deposit's rampant disturbance in spits 1-16 (Di Lello 1997:80-83). The three glazed monochrome sherds in the uppermost spits could represent mortuary offerings dating to approximately 700 B.P. (Bulbeck 1996-97:1026, 1047). To judge from the five determinations on collagen and apatite fractions shown in Table 3 (Bulbeck 1992), the burials probably occurred very approximately between 1000 and 2000 B.P., and would all relate to 
a late use of the interior of Leang Burung 1 as a burial cave, post-dating its period of habitation.

\section{Ulu Leang 1}

Ian Glover has never attempted to disguise the stratigraphic complexities of Ulu Leang 1 (Fig. 3). Sources of disturbance include a shallow fifteenth-century burial in squares C4-5 (Glover 1976:124), fertilizer quarrying in squares E-F/6-7 (Glover 1978:87), profound mingling of prehistoric and recent materials in the $\mathrm{K}-\mathrm{L}$ squares (Glover 1976:122), and slight disturbance affecting the upper spits of the F10 square (Glover 1978:95). In addition, stratigraphic parallels had led Glover to expect a date of 6000-7000 B.P. for charcoal from a hearth excavated in spits 7-8, square J9, which contained abundant rice remains (Glover 1978:97).

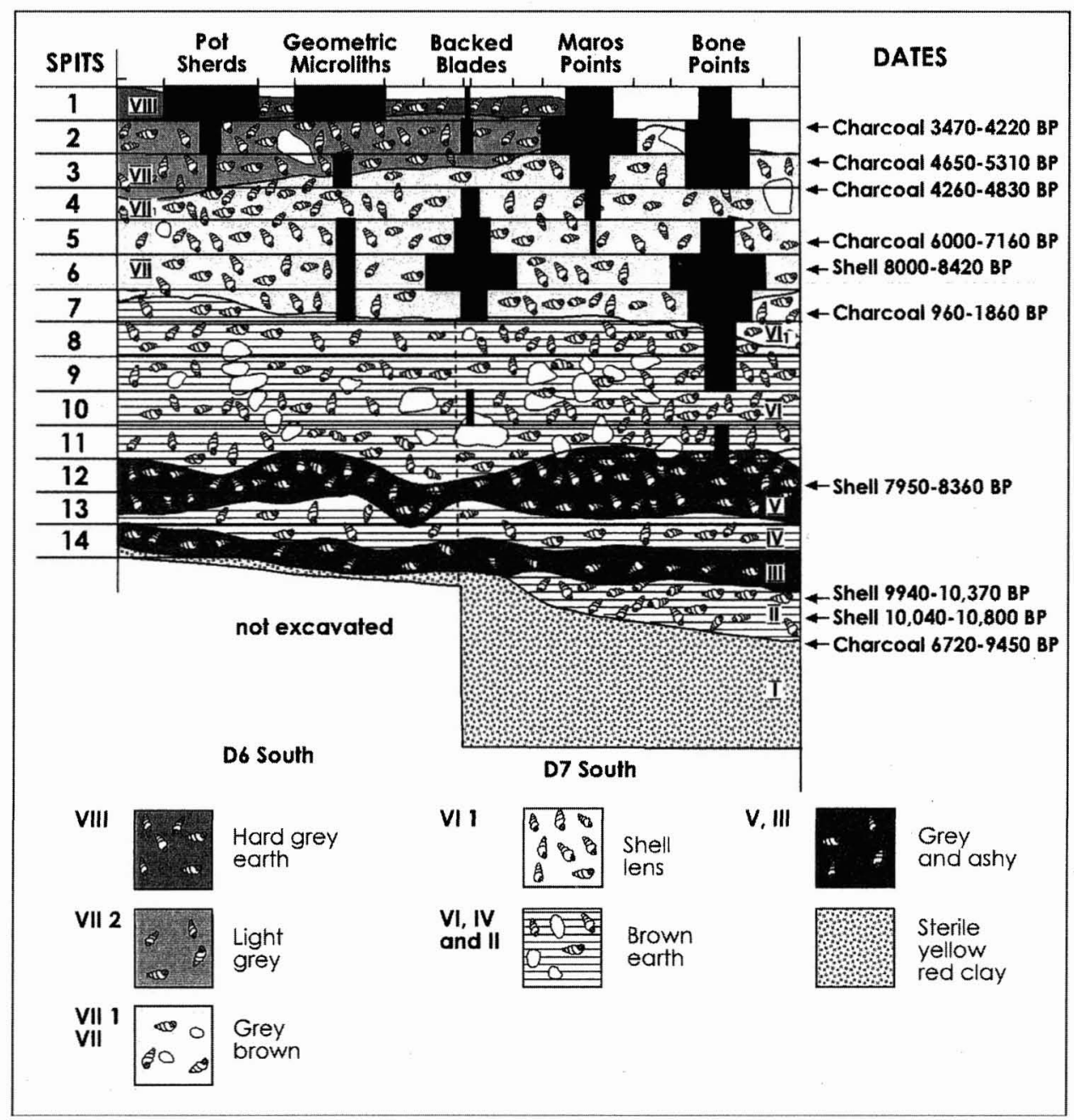

Fig. 3. Schematic representation of artifact type frequencies and chronology at Ulu Leang 1 (adapted from Glover 1976). 
When the charcoal dated to only $1490 \pm 210$ B.P. (Glover $1985: 272$ ), the idea that this rice marked Toalean agriculture in South Sulawesi was placed in abeyance, and the anomalous date was attributed to undetected, localized disturbance. Finally, the deposits have slumped $70 \mathrm{~cm}$ to $2 \mathrm{~m}$ downwards from where cemented deposits mark the old floor level. This slumping, which would postdate the earliest glass at the site (glass was found embedded in the top of the cemented deposit), has significantly warped the site's layers (Glover 1979:307-309).

Glover's main section of the Ulu Leang 1 layers, relating to the D6 and D7 squares, is reproduced in Figure 3. It shows a succession from sterile clay at the base, to layers of brown earth intercalated with gray ashy layers, to a gray-brown layer occupying much of the upper half of the archaeologically productive deposits, and a light gray capping, which may itself be overlain by a hard gray earth. The dated samples (excluding the 1500-year-old hearth in square J9) come from minimally disturbed deposits in squares $\mathrm{C} 2, \mathrm{C} 7, \mathrm{~F} 6-7$, J6, and the cemented deposit (Bronson and Glover 1984:40). As none of them come from squares D6D7, they are plotted on Figure 3 based on the information of which stratigraphic layer and which spit (excavated to $10 \mathrm{~cm}$ in depth) the samples derive from. If this interpretation of the data is permitted, spits 2 and 3 would date to the middle Holocene, spits 5 to 12 would date from $>6000$ в.P. to around 8000 B.P., while the underlying deposits could all date in excess of 8000 B.P.

Glover (1976) provided counts per spit for squares C2-C5 and D6-D7, which lie away from any part of the site known to have been profoundly disturbed. These are aggregated into associations in Table 4, while the earthen sherds and Toalean types are schematically related to the stratigraphy in Figure 3. Spit 1 is clearly a conflated deposit containing materials that date to the last 3500 or 4000 years. In addition to glazed sherds, iron nails, and glass, it contained 72 percent of the pot sherds, 60 percent of the geometric microliths, 24.5 percent of the Maros points, and a few bone points and backed blades. It would broadly relate to the "ceramic Toalean" of spits 1-16 at Leang Burung 1 Trench A, corresponding to a

Table 4. Toalean Types, Potsherds, and Historical Artifacts FROM THE I969 SEASON at Ulu LeANG I

\begin{tabular}{lccccccc}
\hline SPITS & $\begin{array}{c}\text { GLAZED } \\
\text { SHERDS }\end{array}$ & $\begin{array}{c}\text { NAIL + GLASS } \\
\text { FRAGMENTS }\end{array}$ & $\begin{array}{c}\text { EARTHEN } \\
\text { SHERDS }\end{array}$ & $\begin{array}{c}\text { MAROS } \\
\text { POINTS }\end{array}$ & $\begin{array}{c}\text { GEOMETRIC } \\
\text { MICROLITHS }\end{array}$ & $\begin{array}{c}\text { BACKED } \\
\text { BLADES }\end{array}$ & $\begin{array}{c}\text { BONE } \\
\text { POINTS }\end{array}$ \\
\hline 1 & 6 & 4 & 99 & 13 & 6 & 1 & 2 \\
$2-3$ & 0 & 0 & 39 & 36 & 1 & 2 & 10 \\
$4-5$ & 0 & 0 & 0 & 4 & 1 & 18 & 3 \\
$6-11$ & 0 & 0 & 0 & 0 & 2 & 36 & 20 \\
\hline
\end{tabular}

Notes: From Glover (1976: Tables 1, 2, and 4). Backed blades include all of Glover's elongated, blunted-back flakes. Glover's "geometrics" might be an under-representation of the total of geometric microliths, which arguably should have also included "rectangular backed flakes" (see Glover and Presland 1985:191). Miscellaneous points, including elongated and oblique points (Glover and Presland 1985), are not clearly covered by Glover (1976) but would seem to have been present throughout the Toalean sequence at Ulu Leang 1 . The expanded inventories given by Glover and Presland (1985: 190) for the BCD and FG/9-10 squares are not used here owing to the following complications. Glover and Presland (1985:192) included stone points lacking the hollowed base in their sample of Maros points; they did not include pottery or bone points; and the FG/9-10 squares may be suspect given Glover's notification of some disturbance in F10. 
time when the production of Maros points and bone points dwindled, while backed microliths enjoyed some kind of resurgence.

Historical artifacts did not penetrate as deep as spits $2-3$, which contained the remaining earthenware sherds, 68 percent of the Maros points, 29 percent of the bone points, but only 4 percent of the backed microliths. Radiocarbon dates between 3470 and 5310 B.P. are associated with this smattering of backed microliths and concentration of Maros points and bone points. As both the dates and the Toalean typology match those in the preceramic levels at Leang Burung 1, the potsherds in spits 2-3 at Ulu Leang 1 could be intrusive from spit 1 . Although Glover (1979:307) obtained a 4260-4830 B.P. date from 20-40 cm depth in a cemented deposit sample that also yielded 12 pot sherds, a Maros point and 12 geometric microliths (between 0 and $60 \mathrm{~cm}$ in depth), any pottery from the same depth as the dated sample may have been trampled downward prior to the deposits' cementation. The actual dating on the pottery itself is 3000-4000 B.P., being a thermoremnant magnetism assay on sherds from spits 1 to 3 in the C2 square (Glover 1978:94). Thus it is entirely possible that all the pottery at Ulu Leang 1 post-dates 4000 B.P. or even 3500 B.P., and would be generally more recent than the Maros points-the hallmark of the middle Holocene Toalean at Leang-Leang.

The four Maros points in spits 4 and 5 could be intrusive from spit 3. Hence the earliest Toalean assemblage at Ulu Leang 1, which would date to approximately 6000-8000 B.P., is characterized by backed microliths and bone points, but few if any Maros points. Of the geometric microliths, 30 percent came from spits 5 to 7,93 percent of the backed blades came from spits 4 to 7 , the deepest backed blade lay in spit 10, and 66 percent of the bone points were excavated in spits 5 to 11 . This early-middle Holocene Toalean assemblage has no obvious correlate at Leang Burung 1 but compares well with Van Heekeren's lower layer at Leang Pattae.

In summary, the apparent discrepancies in the Leang Burung 1 and Ulu Leang 1 sequences (Chapman 1986) can be resolved by taking account of the conflated status of spit 1 at Ulu Leang 1, and by allowing for post-depositional movement of the Ulu Leang artifacts over 10-20 cm. Further, the main deposits in Ulu Leang 1 contain the early-middle Holocene Toalean assemblage, which is lacking at Leang Burung 1, where, instead, the middle and late Holocene Toalean repertoires are preserved in an uncompressed form. Note also that Glover $(1976: 138)$ reported abundant shell scrapers at Ulu Leang 1. Finally, Glover and Presland (1985: 192) observed that 9 percent of the finished Maros points had bidirectional backing on one or both margins. The last observation illustrates the degree to which backing was employed as a retouching technique in the Maros karsts, in contrast to sites along the Walanae watershed where denticulation seems to have been preferred, even along the haftable margins of microliths.

\section{THE PANGKAJENE KARST SITES}

North of Maros, the karsts continue to abut the coastal plain as far as the present department of Pangkajene Kepulauan. Van Heekeren (1972:111) undertook the original exploration in 1937 with his still unreported excavation at Leang Panameanga. Indonesian archaeologists have executed all of the documented research, 
but have been hampered by lack of access to radiocarbon dates, and an apparent inability (in Bulbeck's experience) to recognize backing on artifacts. Their attention turned to this area after the discovery of a gallery of excellently preserved cave paintings at Sumpang Bita (Suaka 1984). The hand and foot stencils, and the depictions of wild boar, a canoe, and a deer may all be ceramic in age, as pottery was collected from the surface, yet excavation failed to produce any artifacts (Subagus 1986:248-256).

Gua Bulusumi, on the slope beneath Sumpang Bita, contained pottery on its surface, while the excavations yielded stone points including Maros points and bone points (Darmawan et al. 1993:10; Subagus 1986:254, 256-257). Two further sites to the south, immediately north of the Belae karsts, have also been excavated. The cemented deposits of Gua Macinai yielded pottery, an "adze," and unclassified lithics, but no Maros points (Subagus 1986:249, 266). Leang Garunggung produced abundant pottery and lithics, including blades, but no Maros points or bone tools. Apart from two pointed flakes with serrated edges, any modification of the edges was restricted to use-wear, so in this case backed microliths were, indeed, probably absent (Sumantri 1986). Subagus (1986:268) classified the Leang Garunggung assemblage as early Toalean, by comparison with Leang Karassak, but it is clearly a late ceramic Toalean assemblage.

Sumantri (1996) surveyed the limestone shelters of the Belae karsts whose cliffs beetle above an interlacing coastal plain. His surface collections included shell artifacts at 2 of the 22 shelters, miscellaneous stone points at 4 of them, and Maros points at 3 sites (Sumantri 1996:180-182). An earlier survey (Darmawan et al. 1991) reported earthenware sherds in 13 of the 15 inspected shelters, and glazed ceramics in 3 of them. Bone points have not been reported among the faunal remains described from any Belae site.

\section{Open Toalean Sites}

Van Heekeren (1972:123) characterized the Toaleans as "the cave-dwellers of Southwest Celebes." Although they surely spent most of their time outside rockshelters, there was minimal awareness of open-air Toalean sites prior to the 1980s. In 1946, Van Heekeren collected a blade-like stone point (Jakarta Museum Accession No. 5960) at Mandai, $25 \mathrm{~km}$ north of Ujung Pandang (plotted in Van Heekeren 1972, fig. 23). Mulvaney and Soejono (1970a:168) mentioned backed blades in a large surface collection at Campagaloe, but did not provide further details apart from noting the lack of intact stratigraphy (Table 5). Open sites have not been reported from Leang-Leang despite repeated survey of its rockshelters by Dutch archaeologists (Van Heekeren 1972:116-120), and by Mulvaney and Soejono (1970a), Glover (1978), Makkulasse (1986), and Darmawan and Albertinus (1991). In the Belae karsts to the immediate north, Sumantri (1996:96) managed to record a scatter of chert that covered more or less 3 ha of bunded ricefield land. Although these lithics have not been observed in any detail, Sumantri (pers. comm.) has not noted any obvious Toalean types, and he believes the chert had been carried in from a nearby source.

Interest in South Sulawesi open lithic scatters used to be focused on the terraces of the Walanae Valley. This reflected the early Pleistocene or even older dating formerly entertained for these "Cabenge" lithics, currently assigned to the 
Table 5. Summary of Observations from Open Toalean Sites

\begin{tabular}{|c|c|c|c|c|c|}
\hline SITE & $\begin{array}{l}\text { BACKED } \\
\text { BLADES }\end{array}$ & $\begin{array}{c}\text { GEOMETRIC } \\
\text { MICROLITHS }\end{array}$ & $\begin{array}{l}\text { MAROS } \\
\text { POINTS }\end{array}$ & $\begin{array}{c}\text { OTHER STONE } \\
\text { POINTS }\end{array}$ & $\begin{array}{c}\text { EARTHEN } \\
\text { SHERDS }\end{array}$ \\
\hline \multicolumn{6}{|l|}{ Central-West Coast } \\
\hline Mandai & - & - & - & $x$ & \\
\hline Belae & & & -? & —? & \\
\hline Padang Lampe & & & $x ?$ & $x$ & \\
\hline \multicolumn{6}{|l|}{ South Coast } \\
\hline Campagaloe & $x$ & - & - & & \\
\hline \multicolumn{6}{|l|}{ Bone and Soppeng } \\
\hline Ujung & - & - & - & $x$ & $x$ \\
\hline Cabenge & & & - & $x$ & \\
\hline Watanlamuru & & & $x ?$ & & \\
\hline Malindrung & & & - & $x$ & $x$ \\
\hline \multicolumn{6}{|l|}{ Selayar Island } \\
\hline Batang Mata Sapo & & & $x$ & & \\
\hline \multicolumn{6}{|l|}{ Macassar Survey Area } \\
\hline Bonto Sunggu Âsli & 1 & - & - & - & 567 \\
\hline Gentung & - & 2 & - & $x$ & 6 \\
\hline Pakka Mukang & - & 2 & - & $x$ & 964 \\
\hline Balang Sari & & 1 & - & $x$ & 2002 \\
\hline Bonto Ramba Tua & - & 1 & - & $x$ & 680 \\
\hline Saukang Boe & - & 1 & - & & 65 \\
\hline $\begin{array}{l}\text { Pammangkulang } \\
\text { Batua }\end{array}$ & - & - & 7 & $x$ & 57 \\
\hline Bukit Bikulung & - & - & 2 & $x$ & 25 \\
\hline Salekowa Tua & - & - & 2 & $x$ & 104 \\
\hline Moncong Moncong & - & - & 1 & - & 0 \\
\hline
\end{tabular}

Note: Bone points have not been reported from any open Toalean site, presumably owing to the poor preservation of exposed bone. $\times$ signifies presence, - signifies absence, blank spaces signify no evidence, and question marks indicate dubious observations.

late Pleistocene (Keates and Bartstra 1991-92). As part of his investigations Bartstra (1978:71) reported small stone artifacts, including hollow-based points with denticulated sides, along the present banks of the Walanae. Bartstra (pers. comm.) now indicates that these "Maros points" were apparently restricted to Watanlamuru, and recommends their re-examination as their precise morphology may not have been adequately recorded in the field. According to the Suaka field archaeologist based at Cabenge, miniature serrated points are occasionally observed as surface finds along the lower Walanae Valley, but they always lack hollowed bases (Bulbeck 1995:5).

Two later surveys recorded Holocene lithics along the valley. Bulbeck (1989) collected four knapped lithics during a survey of historical sites associated with the Bugis kingdom of Soppeng. They include an asymmetrical point, with serrated dorsal retouch along both margins near the tip, from Ujung. In 1987 Bulbeck supervised the mapping and collection of an extensive lithic scatter, spatially associated with earthenware pottery, at Malindrung in the Upper Walanae. Budianto Hakim (1990), who studied the collection for his Honors project, coined the term "Malindrung point" for stone points that have serrated margins but lack basal hollowing. Hakim's Malindrung points would equate to Chapman's (1981, 
1986) serrated miscellaneous points, with a morphology observed throughout the peninsula from Cabenge southwards.

The same points are certainly present at Padang Lampe near Ralla in the department of Barru. Points made of local silicified limestone were recorded at four of the open-air scatters including, in three cases, serrated and unserrated arrowheads (Darmawan et al. 1993). Unfortunately, none of these arrowheads is illustrated, but according to a local archaeologist who helped to supervise the surveys, some of them have hollowed bases (Tanwir L., pers. comm.).

The most systematic recording of lithic scatters in South Sulawesi occurred in 1986-87 during SSPHAP's Macassar survey in the southwest of the peninsula (Fig. 1). The survey attempted a 100 percent survey of the burial grounds and major settlements dating between the thirteenth and seventeenth centuries A.D. (Bulbeck 1992:189). Any lithics observed during reconnaissance or the mapping of the targeted historical sites were recorded and collected. This initiative resulted in 68 lithic scatters and isolated finds, including 4 sites with Maros points and 6 with backed microliths (Fig. 4). Although the SSPHAP sample did not accrue specifically from a probabilistic strategy, being a bonus generated during the universal survey of a different class of sites, neither is it the sort of clearly biased sample that "hunch sampling" tends to produce. We contend that it is valid to treat the sample as representative (cf. Ammerman 1981) even if our resulting inferences should still ideally be tested through an explicitly probabilitistic survey.

In all, 1764 knapped stone artifacts were collected for documentation in the laboratory. The data in Table 5 for Pammangkulang Batua come from Pasqua (1995) and the other data are revised and expanded from Bulbeck (1992). They show 12 Maros points in all, numerous other stone points, 1 backed blade, and 7 geometric microliths. Hence a very small proportion of all the knapped lithics, approximately 1 percent, consists of "classic" Toalean types. This proportion would be higher if we could identify and include all failed, discarded attempts at Toalean types (cf. Williamson 1990), but the only two cases of which we felt confident are T.28.1.274, an unfinished Maros point from Salekowa Tua (Fig. 5), and G.59.2.34, an unfinished geometric microlith from Gentung.

Only backed microliths or Maros points were recorded at any site, never both. This probably reflects chronological differences rather than discrete site function. Earthenware sherds show a lower ratio compared to Maros points $(0-52)$ than the backed microliths do (65-1001), with the sole exception of Gentung. This suggests that the production of Maros points rapidly declined after the introduction of pottery, whereas backed microliths continued to be produced. Gentung, with two geometric microliths but only five earthenware sherds, could represent either an early Toalean site predating the appearance of Maros points, or a small middle Holocene assemblage ( 51 lithics) lacking Maros points by chance.

Some level of chronological control is provided by the radiocarbon date on intertidal shellfish collected from villagers' wells at Bone-Bone, plotted on Figure 4. The original date, $5800 \pm 90$ B.P. (ANU-5925), calibrates to 5990-6390 в.P. at two-sigma after application of the "model ocean marine mixed layer" (not $4290 \pm$ 100 B.P. as erroneously reported in Bulbeck 1992:202). The top of the wells lie at $8 \mathrm{~m}$ above present sea level, and the shellfish were found between 7.5 and $9 \mathrm{~m}$ below the surface (Bulbeck 1992:202). The shellfish sample therefore corresponds perfectly to the 6000 B.P. interval when South Sulawesi's sea levels rose to 


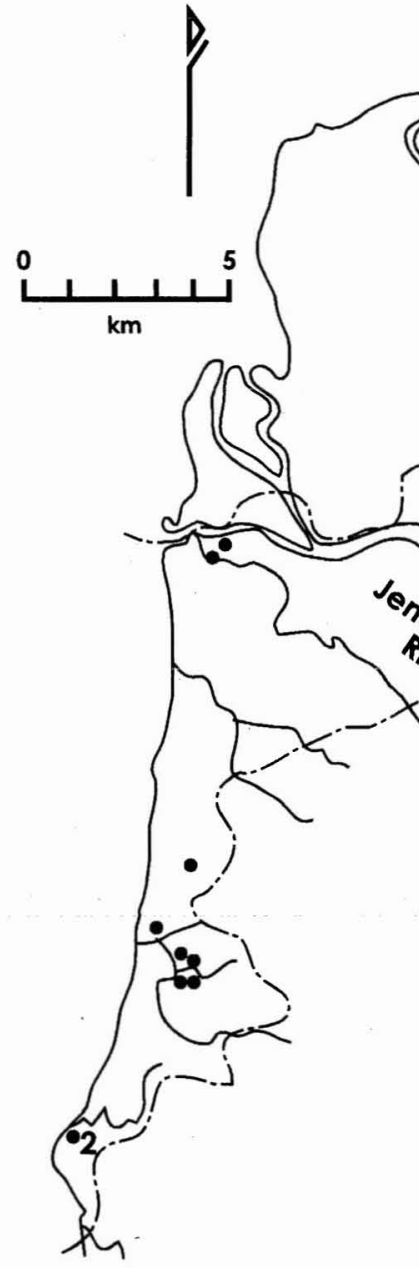

Backed Blades

1. Bonto Sunggu Asli

\section{Geometric Microliths \\ 2. Pakka Mukang \\ 3. Balang Sari \\ 4. Bonto Ramba Tua \\ 5. Saukang Boe \\ 6. Gentung}

Q Baturape-Cindako Vocanics

\section{j Macassar Survey}

Tallok River

Fig. 4. Sites with flaked lithics inside the Macassar survey area.

their present level (Whitten et al. 1987:19-20). Between the depths of 6 and 7.5 $\mathrm{m}$ in the wells, the deposits consisted of silts and black sand mixed with some shell grit. This would correspond to the middle Holocene period during which sea levels kept rising until about 4500 B.P., when they peaked at $5 \mathrm{~m}$ above their 

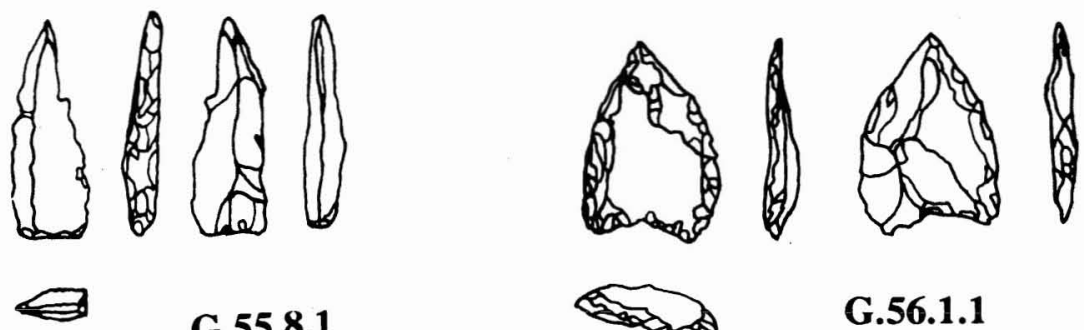

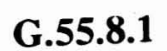 \\ G.55.8.1}

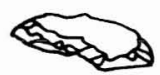

G.56.1.1
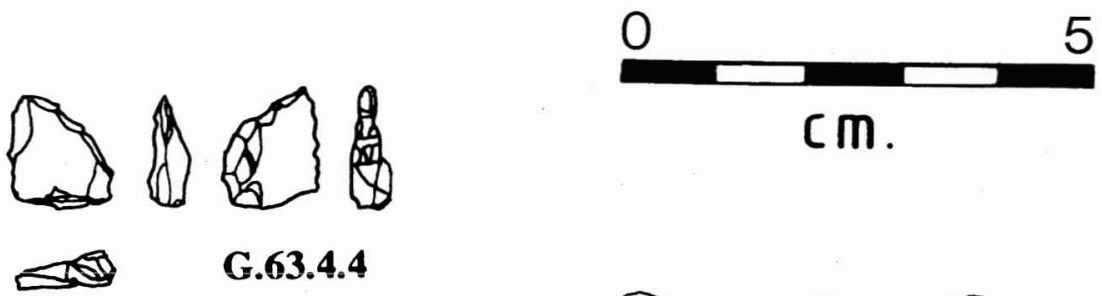

cm.
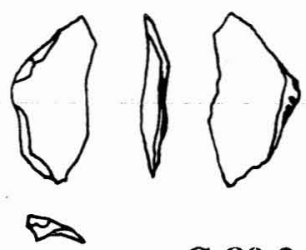

G.80.2.2
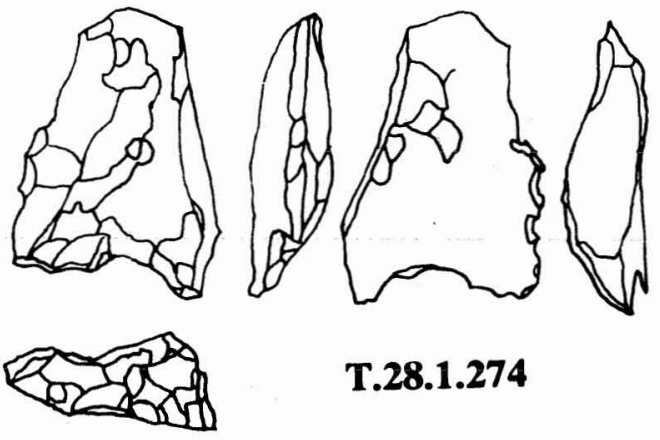

T.28.1.274

T.28.1.337
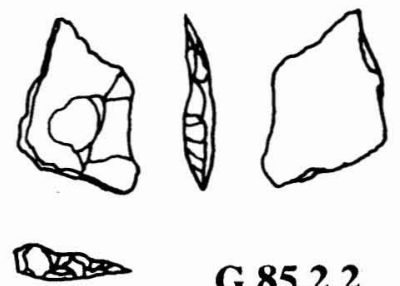

\section{G.85.2.2}
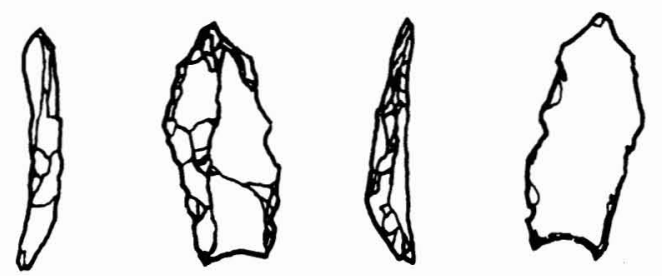

Fig. 5. Representative classical Toalean lithics from the Macassar survey. G.55.8.1: backed blade, Bonto Sunggu Asli. G.56.1.1: Maros point, Moncong Moncong Baru. G.63.4.4: geometric microlith, Balang Sari. G.80.2.2: geometric microlith, Saukang Boe. G.85.2.2: geometric microlith, Bonto Ramba Tua. T.28.1.274, T.28.1.337: Maros points, Salekowa Tua.

present level. Hence the top $6 \mathrm{~m}$ of alluvium across most of the Macassar survey area would have been deposited in the last 4500 years, and no doubt more recently along the coastal strip west of Bone-Bone.

Following Bulbeck (1992, fig. 5.2) the survey area can be divided as follows. Old land surfaces are represented by the Miocene Camba Formation (marine sedimentary and volcanic rocks) and the Pliocene Baturape-Cindako volcanics; any 
Table 6. Distribution of Lithics in Sites in the Macassar Survey Area

\begin{tabular}{|c|c|c|c|c|}
\hline & $\begin{array}{c}\text { NON- } \\
\text { ALLUVIAL }\end{array}$ & $\begin{array}{l}\text { MIDDLE-LATE } \\
\text { HOLOCENE } \\
\text { ALLUVIAL }\end{array}$ & $\begin{array}{c}\text { RECENT } \\
\text { ALLUUVIAL }\end{array}$ & TOTAL \\
\hline Toalean sites & 6 & 3 & 1 & 10 \\
\hline Other sites with flaked stone & 36 & 9 & 13 & 58 \\
\hline All sites with flaked stone & 42 & 12 & 14 & 68 \\
\hline All recorded sites & 51 & 33 & 79 & 163 \\
\hline
\end{tabular}

Data from Bulbeck (1992, Appendix C).

middle Holocene alluvial surfaces would lie east of Bone-Bone; and the alluvial surfaces west of Bone-Bone are late Holocene (see Fig. 4). SSPHAP's total sample of 163 historical sites splits fairly evenly among these three surfaces-31.2 percent, 20.2 percent, and 48.5 percent, respectively (Table 6). Lithics are usually present at sites on nonalluvial surfaces ( 82.4 percent), often present at sites on middle Holocene alluvium (36.4 percent), and rare at sites on late Holocene alluvium (17.7 percent). Statistically, the difference between the land surfaces in their proportion of sites with or without lithics is highly significant (Chi-square $=53.6$, $2 d f, p<0.005$, Cramer's $v=0.16$ ). This result conforms to the expectation that stone knapping waned in importance during the late Holocene. It would follow that most of the lithic scatters on nonalluvial surfaces would predate the late Holocene. Fully 82 percent of the historical period sites in this land unit coincided spatially with lithic scatters, suggestive of a well-settled population of early to middle Holocene inhabitants.

From geomorphological considerations, the two geometric microliths found on the Pakka Mukang chenier (along with 240 other flaked lithics) would date to the late Holocene, perhaps 1000-2000 years ago. The high ratio of 482 earthenware sherds to each geometric microlith supports this view. Nonetheless, we find some support for the case that stone flaking continued for some period after the production of "classical Toalean" tools had effectively ceased. Only 7.1 percent of sites with lithics along the coastal strip have Toalean types, compared to 16.7 percent on older alluvial and nonalluvial surfaces.

\section{TEMPORAL AND CHRONOLOGICAL VARIATION IN THE TOLEAN}

Despite considerable survey and excavation in the Cenrana Valley (Bulbeck 1996-97, 2000c), Toalean sites have not been recorded there, nor in the Tempe graben or the land below $100 \mathrm{~m}$ a.s.l. west of Lake Tempe (Fig. 1). These three geographical features lie along a transpeninsular stretch of lowlands that, according to local stories, used to lie underwater and permit boats to sail from one coast to the other (Whitten et al. 1987:20). Nor are there any known Toalean traces in the northern third of the South Sulawesi peninsula, despite sustained archaeological research there. The hills directly north of Lake Sidenreng from Enrekang to Toraja have numerous caves with archaeological remains but, as yet, no reports of Toalean artifacts (Bernadeta 1998; Darmawan et al. 1994; Suaka 1986). As far back as 1939, Willems had explored rockshelters in the Toraja highlands, seeking evidence of the Toalean in vain (Van Heekeren 1949:94). Excavations of four 
Neolithic to Metal Age sites along the Karama River, due west of the Toraja highlands, have not unearthed any Toalean traces (Van Heekeren 1972:185-190; Simanjuntak 1994-95). In Luwu to the east of the Toraja highlands, thousands of flaked stone artifacts have been recorded at twelve sites (Bulbeck and Prasetyo 1999; Bulbeck 2000d), none of them typologically Toalean. Accordingly it would appear that the northern boundary of the Toalean is marked by a saline channel (or belt of swampy land) that had stretched across the peninsula in the region of the Tempe depression during the middle Holocene (cf. Caldwell and Lillie in press; Gremmen 1990).

A sea barrier (if such a feature had indeed traversed the peninsula) would not in itself have presented a sufficient impediment to the spread of the Toalean. Hakim (2000) recently reports the recovery of Maros points at Batang Mata Sapo on Selayar Island, located $30 \mathrm{~km}$ off the peninsula's southeast coast. Hence we suggest that the Toalean, as a "mesolithic" phenomenon characterized by an array of typologically well defined implements, was focused on the southwestern third of the peninsula, with a possible extension to Selayar. Northwards of Lamoncong and Pangkajene, the Toalean appears in an attenuated form in which miscellaneous stone points, such as "Malindrung points," and bone points stand out as the salient types (Tables 1 and 5). This attenuation increases as we move farther north into the Cenrana Valley and the northern third of the peninsula, where all traces of the Toalean disappear. We highlight this spatial patterning with the "classical Toalean" line drawn in Figure 1, marking the northeasterly distribution of secure cases of Maros points (Tables 1 and 5), although we accept it could arguably be extended slightly to include Padang Lampe and Watanlamuru.

Van Heekeren (1972:123) summarized the Toalean as "a real microlithic industry with a remarkably large number of geometric microliths, thus far the only one found in Indonesia." From the evidence presented here, backed microliths may have been present only along the south coast of the peninsula and the southwestern lowlands (Tables 1 and 5) - a distribution even more restricted than the "classical Toalean" indicated in Figure 1. Although more widespread, Maros points appear particularly common along an axis slanting from the Macassar survey area in the southwest, through Leang-Leang, to Lamoncong in the northeast. Where Maros points are present along the south coast, the hollowing of the base appears small or even vestigial, although we would not go as far as Chapman $(1981,1986)$ and expel these cases from the said class.

Where we emphatically agree with Chapman (1986) is her summary of the Toalean as a common technological tradition marked by local specializations. Chapman's conclusion, based on metrical features of the points, scrapers, and backed microliths, is confirmed by Pasqua's technological study of the lithics from Leang Burung 1, Leang Karassak, and Pammangkulang Batua. In all cases the debitage patterning conformed to Flenniken and White's (1985) model of core reduction in Australian industries. For instance, the ratio of blades to flakes was always low $(1: 55$ to $1: 149)$. Differences in the precise strategy at the three Toalean sites can be attributed to variation in the quality and availability of suitable stone, rather than the production of different formal tools. Thus, stone points (made from medium-sized flake blanks, according to Flenniken and White's model) constituted 2-3 percent of each assemblage, even if the proportion reshaped into Maros points varied substantially (Pasqua 1995; Pasqua and Bulbeck 
1998). Following the definitions of Bahn (1992), Pasqua characterized the Toalean as a single tradition, unified by points and microliths produced with an Australianlike technology, but she rejected the notion of a single industry owing to the variability in formal tools.

The Toalean is not in evidence at the onset of the Holocene. At both Panganreang Tudea (Van Heekeren 1972:114) and Ulu Leang 1 (Glover 1976:127, 139-142), the deepest morphologically Toalean artifacts were underlain by generally larger lithics including scraper-like retouched flakes. Similar "scrapers" and other utilized flakes are of course observed in every substantial Toalean assemblage that has been subjected to close analysis (e.g., Chapman 1986; Di Lello 1997; Glover 1976). Round- and straight-based stone points (often with serrated margins), bone points, and shell scrapers would appear to have been added to the repertoire of tools at 7000-8000 B.P., to judge from the Ulu Leang 1 sequence. These artifacts are present across the peninsula south of the Cenrana Valley, suggesting that they spread on account of the advantages they offered to huntergatherers' survival, whether or not there had been much human migration. The bone and shell artifacts (which are certainly not in evidence at every site) can be interpreted as adaptative utilization of materials that would otherwise have been ignored or wasted. The stone points were surely hafted to shafts for use as projectiles, as the "spearhead" and "arrowhead" classifications in our literature review imply.

The more restricted distribution of the backed microliths and Maros points would therefore suggest more limited adaptative advantages, at least compared to the costs of making them. For instance, the hollowed base of Maros points may have enhanced their efficiency as arrowheads by reducing their weight (cf. Cotterell and Kamminga 1990:181) and making it easier to haft them. However, the blanks would have been prone to breakage when the bases were hollowed (Williamson 1990:29), so less confident knappers may have considered that step imprudent. Sure, there may have been specific environmental factors that selected for the more localized types within their areas of distribution, but if so, they cannot be easily identified. Throughout the peninsula the climate is monsoonal, the soils are fertile (Whitten et al. 1987), and the faunal assemblages include large mammals like anoa buffalos and suids, medium-sized mammals such as monkeys, and small mammals such as rodents (Hooijer 1950; Simons 1997). Presumably, less specialized tools supplied the same function; "Malindrung points" served as serrated arrowheads beyond the range of Maros points, and denticulated microliths were used as spear barbs beyond the range of backed microliths. From the available evidence, the Toalean can thus be considered a tradition that encompassed spears (bone points may also have been used as spearheads), bow-andarrow technology, and abundant "maintenance" tools such as scrapers.

The restricted chronology of the Maros points, approximately 5500-3000 в.P. at Leang-Leang (Glover and Presland 1985; Presland 1980:36-39; this paper), sits comfortably with their limited geographical spread. The backed microliths are more problematical given their longevity of production, which started before the Maros points, yet continued until 2000 B.P. or later (Glover and Presland $1985: 193$; this paper). They had become fixed in the technological repertoire of hunter-gatherers in southern South Sulawesi for as long as 6000 years, yet people to the immediate north never seem to have embraced their manufacture at 
archaeologically visible levels. Backed microliths may have spread far and wide across Australia as a means of reducing hunter-gatherers' risk (Hiscock 1994), but we hesitate before splitting South Sulawesi into high-risk and low-risk environments along our "classical Toalean" line. If South Asian backed microliths were the prehistoric ancestor of their Toalean counterparts, as suggested by Glover and Presland (1985:193-194), this would hardly explain why these tools seemingly failed to reach the Walanae Valley. We suggest that backed and denticulated microliths were entirely viable alternatives as spear barbs. Manufacture of the backed variant was maintained along the southern coasts and foothills through continuous social interaction in this region, providing a buffer against the localized extinction of a useful but, ultimately, expendable technology.

Our classical Toalean line in Figure 1 closely matches the major cordillera of the South Sulawesi peninsula. It is a chain of volcanic and uplifted marine rocks that separates the foothills and attached plains of the southwest from the rolling landscape of the Walanae Valley and the east coast. Interaction between these two regions would have been limited whereas, within each region, a network of trails would have facilitated access to water sources, stone quarries, foraging patches, gaming locations, and members of neighboring bands. We propose that the longterm maintenance of two mobility networks, either side of the classical Toalean line, accounts for the longevity of backed microliths in the southwest quarter, and the similar geographical distribution of the middle Holocene Maros points. We also suggest that the same factor lies at the basis of the distribution of the peninsula's Austronesian languages - essentially, Makassar languages to the southwest and Bugis to the northeast-as will be discussed in the concluding section of this paper.

\section{COMPARABLE HOLOCENE ASSEMBLAGES IN ISLAND SOUTHEAST ASIA}

Holocene assemblages characterized by small stone artifacts occur in an arc from central Sumatra, through the Sundas and eastern Indonesia, to the islands that border the Sulu Sea (Fig. 6). As this distribution closely corresponds to the location of obsidian and fine-grained siliceous stone in Island Southeast Asia, the local availability of high-quality knapping material must have underwritten the establishment of these microlithic industries. Further, the few documented late Pleistocene assemblages from the same localities exhibit typically larger debitage pieces and stone tools (see Bellwood 1997). That is, as stone of suitable quality became rarer during the Holocene, its rationing arguably guided the shift towards small lithics. As we shall discuss, small size of the artifacts (readily attributable to local adaptation) is about the only generalization that can be applied to Island Southeast Asia's "flake-blade" assemblages. Where we might seek evidence of long-distance interaction, such as the exchange of obsidian away from its source areas, the results are decidedly negative until the late Holocene. From that perspective, our division of the Toalean into northeast and southwest facies, and the restriction of the Toalean to the South Sulawesi peninsula, epitomize the diversity among Island Southeast Asia's microlithic industries.

Possibly the earliest assemblage of relevance here comes from Tianko Panjang, central Sumatra, dated to c. 10,000 B.P. at its base, and continuing till ceramic times. Small nodules of local obsidian were utilized to detach typically small flakes, 


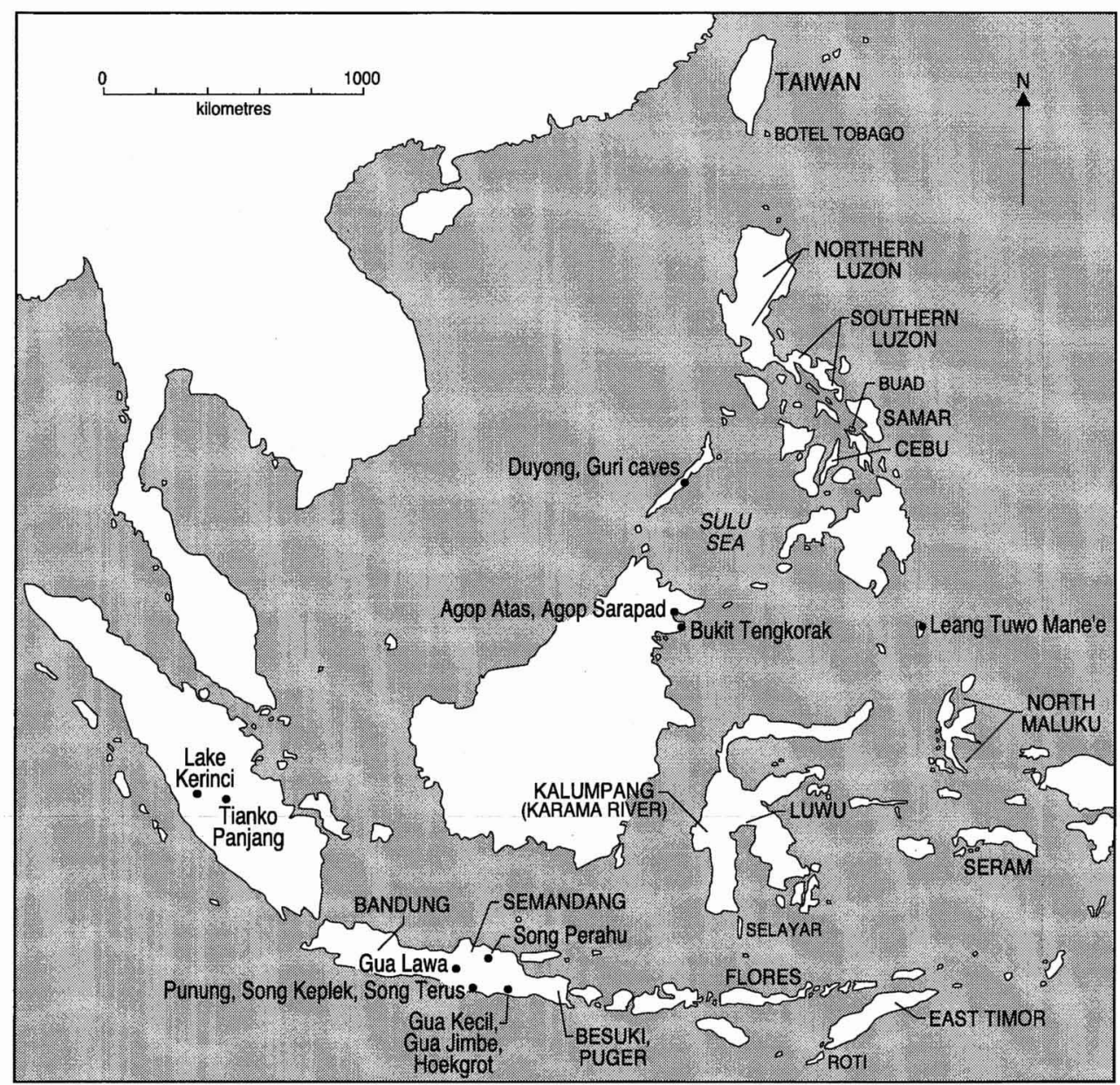

Fig. 6. Places with lithics in Sulawesi (outside of the southwest peninsula) mentioned in the text, and other referenced sites and areas.

very few of them either retouched or classifiable as blades (Bronson and Asmar 1975). Bronson and Asmar assert that the assemblages from Tianko Panjang and Ulu Tianko (5 km away) compare favorably, although Van Heekeren (1972:137138) reports retouched arrowheads and borers among the obsidian artifacts in the latter site. Backed crescentic microliths occur as a rare element in the surface scatters of obsidian at Lake Kerinci, a short distance to the west (Glover and Presland $1985: 188)$.

Prehistoric Holocene assemblages in Java are characterized by bone artifacts (when preserved in rockshelters) and small stone tools but, otherwise, enormous variability. Surface assemblages of local obsidian near Bandung, west Java, are broadly similar to their central Sumatran counterparts. "Mesolithic" types include slender projectile points, sometimes retouched along one margin and the butt, backed crescents, borers, and knives (Bellwood 1997:198; Glover and Presland 1985:188; Van Heekeren 1972:135-137). Subagus (1979) suggested an early 
Holocene to "Neolithic" chronology, and also observed that retouched scrapers are the most common tool. Quite different assemblages have been recovered from the preceramic levels at four limestone shelters near Besuki and Puger in east Java. Van Heekeren (1972:100-104) mentions numerous bone artifacts including an arrowhead, convex-based stone arrowheads, pebble tools, and, in one site, unretouched obsidian flakes and abundant shell scrapers. Further, Storm (1995:148) cites mean radiocarbon determinations between 3265 and 2650 B.P. (uncalibrated) from three rockshelters in east Java with bone tools: Gua Kecil, Gua Jimbe, and Hoekgrot. As pottery is evident only at Hoekgrot, these three sites suggest that certain communities in Java did not acquire pottery until after 3000 years ago.

Adding to this picture of diversity, bifacially trimmed arrowheads (some with hollowed bases) have been found only in central Java. They are associated with bone tools and, occasionally, shell scrapers and antler tools. Representative sites include numerous limestone shelters in the Semandang district of north-central Java, surface scatters in the Punung hills of south-central Java, and Gua Lawa in between (Van Heekeren 1972). Forestier (1999:133-135) suggests a dating of around 4000-5000 B.P. for this "Sampung industry" as older assemblages present a different character. The Song Keplek assemblage in south-central Java, dated to c. 4500-6000 B.P., features spatulas and points of bone plus small, notched chert implements including scrapers, denticulates, and convex-based points. Similar "Mousterian microlith" and bone tools are dated to c. 6000-8000 B.P. at the adjacent rock shelter of Song Terus (Forestier 1999; Simanjuntak 1995-96). Simanjuntak (1994-95) cites a further radiocarbon date of about 7000 B.P. for "flake-blade" lithics and bone tools from Song Perahu, north-central Java. Note that the very limited spatial and chronological extent of Java's bifacially trimmed arrowheads parallels the situation with Maros points in South Sulawesi to a remarkable degree.

Holocene lithics in the lesser Sundas tend to be assigned to a "flake-blade technocomplex" characterized by rare bladelets and irregularly notched or otherwise retouched tools. The local availability of obsidian and fine-grained siliceous stone (Lie 1965; Van Heekeren 1972) would not appear to have led to the development of identifiable types. Representative sites on Flores include Leang Bua, with its small flakes dating back to around 10,000 B.P. (Simanjuntak 1995-96:21; Sukadana 1981), and the eight sites discussed by Van Heekeren (1972:140-147). Of these, Leang Toge (with a radiocarbon date of around 3500 B.P.) also yielded two shell scrapers, while Gua Rundung produced points and other artifacts of shell and bone. Van Heekeren (1972:148) further reported stone knives, points, and borers from Lua Neoal in Roti, and a scraper of tortoise shell.

Further to the east, a surface collection of lithics in Seram contained occasional blades and points with retouched butts, presumably to assist hafting, utilized flakes, and sparse burins (Glover and Ellen 1977). Timor has a unique microlithic "type" in the form of small tanged points, though in East Timor these were found only in pottery-bearing layers (Glover 1986). Otherwise the East Timor chert lithics appear remarkably homogeneous from around 8000 to 2000 B.P. Burins, small to medium-sized scrapers, and flakes and blades with silica gloss on their edges constitute the salient tools. Tiny flakes of local obsidian constitute a minuscule element. Shell scrapers and other artifacts are common but artifacts of bone appear scarce or absent (Glover 1986). In stark contrast, all four excavated 
assemblages dated between 7000 and 3000 B.P. in North Maluku include bone points, but flaked stone is rare to absent (Bellwood 1997:188). This last observation reflects the poor knapping quality of the locally available stone and, by induction, the dependence of "flake-blade" assemblages on high-quality stone.

Flake-blade industries are not in evidence in the environs of the Sulu Sea before 7000 B.P. The Paso shell midden in North Sulawesi, dated to around 8500 B.P., features local obsidian smashed into lumps and chips, or occasionally retouched to produce steep-edged tools. Only the bone points (rare to absent in other assemblages in the region) could be considered at all "mesolithic." In Sabah (northeast Borneo), Agop Atas and Agop Sarapad yielded steep-edged chert tools and utilized chert flakes dated to approximately 10,000-7000 B.P. (Bellwood $1997: 180-181,185)$. The earliest blades in the vicinity would date to 7000 B.P., according to the radiocarbon determination on the small blades and flakes, with occasional notched retouch, recovered from a midden at Duyong Cave, Palawan. Guri Cave, also in Palawan, yielded blades and small retouched flakes dated to after 4000 B.P. (Fox 1970). A similar preceramic assemblage is dated to c. 60004000 B.P. at Leang Tuwo Mane'e in the Talaud Islands, between Maluku and Mindanao. "[These] deposits produced an industry comprising blades and bladelike flakes (about 50 percent of all stone), together with some rather rudimentary prismatic cores, made on a grey chert" (Bellwood $1997: 191)$.

Small quantities of obsidian may have moved around the Sulu Sea on the eve of the arrival of pottery. At the same level as its lowest potsherds, Leang Tuwo Mane'e produced a nodule of obsidian. Its closest possible sources would lie 100 or more kilometers to the south (Bellwood 1976:261). Obsidian with the same chemical composition accounts for most of the obsidian in the basal six spits at Bukit Tengkorak, in Sabah. Almost 12 percent of this site's obsidian, all of which would have been imported, but only 2 percent of its potsherds occur in these spits. Downward post-depositional movement of some or all of these artifacts is indicated by the site's basal radiocarbon date of around 6000 B.P., calibrated (see Chia 1998a, 1998b). Nonetheless Bukit Tengkorak, along with Leang Tuwo Mane'e, suggests movement of local obsidian shortly before, or as early as the 3500-4000 B.P. dating entertained by Bellwood (1997) for the oldest pottery in the vicinity of the Sulu Sea.

The middle and upper levels of Bukit Tengkorak are agreed to date to about 3000 B.P. and 2800-2100 B.P. respectively (Bellwood 1997:224-227, pers. comm.; Chia 1998b). As of 3000 B.P., the Bismarck Archipelago in Papua New Guina, $8000 \mathrm{~km}$ to the east, emerged as the major supplier of Bukit Tengkorak's obsidian (Chia 1998b). Equally remarkably, awls and other tiny blades detached from prismatic cores of agate occur throughout the Bukit Tengkorak deposits. Bellwood (1997:227) stresses the uniqueness of this industry within a Southeast Asian context, and draws a parallel with broadly contemporary microblade production in South China. However, central Java, Timor, and southwest South Sulawesi also exhibit unique microlithic variants of middle to late Holocene antiquity, so the capacity for local specialization emerges as a feature of the "flakeblade" industries. We propose interpreting the Bukit Tengkorak agate industry as an intensification of the trend, already seen in the preceramic levels at Leang Tuwo Mane'e, towards small prismatic cores. Our proposal would not, however, imply that the wealth of shell artifacts, red-slipped pottery, and polished stone 
adzes at Bukit Tengkorak be viewed as anything other than new technological skills introduced by Austronesian immigrants from farther north (cf. Bellwood 1997).

Blade industries spanned the preceramic-ceramic divide in the central Philippines. Scheans et al. (1970) located numerous open sites with chert microblades on Buad, Daram, and surrounding islets, including retouched tools identified as knives, borers, burins, and scrapers. Scheans et al. suggest a preceramic antiquity on the basis of a lack of associated pottery. Using the same logic, Tenazas (1985) claims a preceramic age for the assemblages of quartz and chert flakes and blades, some retouched into points, and shell blades at Carcar, Cebu. Yet parallel-sided chert blades struck from carefully prepared cores are dated to the "late Neolithic," approximately 2000 years ago, in the Sorsogon and Albay provinces at the southern tip of Luzon (Fox 1970:50). Undated assemblages with a distinct component of blades have also been recorded in southern Samar (Scheans et al. $1970: 180)$. As these authors note, the size of the artifacts, whether blades or microblades, would appear to depend on the size of the available nodules of knapping stone. This would be another reason to regard the agate industry at Bukit Tengkorak as an endogenous development within a region where blades figured far more prominently than they did farther south, and where the appearance of pottery arguably had little discernible effect on local knapping practices.

Blades in the circum-Sulu Sea assemblages presumably served as the functional replacement of the stone and bone points that, individually or jointly, are in evidence everywhere else within the region surveyed here. Discussing Mesolithic Europe, Mithen (1994:97) suggests that microliths made from blades may have best suited the ideal qualities of an arrowhead: the ability to penetrate and produce sharp cuts, and the symmetry to stabilize the arrow's flight. Nonetheless, blades would also appear well-suited as spearheads and spear barbs, depending on size, as indicated by Fox's (1970:48-50) emphasis on blades as hafted tools. Accordingly the very diverse constitution of the "flake-blade" industries discussed here can be attributed to different means towards the same end: improved spear technology, and the spread of archery. The technical exigencies in producing serviceable bows (Cotterell and Kamminga 1990:181-182) suggest that, at least in the case of archery, the technology diffused during the early Holocene with probably no instances of "independent invention." However, the variety of arrowheads suggests localized craft virtuosity and, in many cases, adapting preexisting skills to suit the novel technology. Hence the differences within the Toalean tradition can be viewed as the microcosmic expression of a much greater variability across a larger geographical canvas, involving divergent solutions to improved projectile technology.

Even greater variability would undoubtedly be evident if we could have included points of bamboo and other unpreserved materials. Presumably, organic materials were used to produce small implements in areas lacking the fine-grained stone found in flake-blade assemblages. Surely, by the early to middle Holocene, archery and potent spears were employed well beyond the area where we are fortunate enough to have the relevant information fossilized in the archaeological record. In that context, note that projectile points of polished slate, similar to Neolithic Taiwan examples, appear restricted within Island Southeast Asia to Botel Tabogo, northern Luzon, and the Karama River in central Sulawesi 
(Bellwood 1997:220-229). Their mutually exclusive occurrence with respect to known flake-blade assemblages strongly suggests that an exogenous, "Neolithic" technology served hunters only where appropriate projectile points of chipped stone had not been previously developed. When it comes to stone projectile points, any Austronesian immigrants from Taiwan would appear to have adopted the local knapped varieties (where available), and indigenous hunters may well have borrowed polished stone technology where they lacked suitable flaking stone.

\section{TOALEANS AND EARLY AUSTRONESIANS}

As shown in Figure 1, there is an extremely close match between the documented extent of the classical Toalean, and the dividing line between South Sulawesi's Makasar and Bugis languages (Grimes and Grimes 1987). Could this suggest early to middle Holocene diversification of Austronesian languages within Island Southeast Asia? Reconstruction of the bow in proto-Austronesian (Blust 1995 : 475) might be construed as linguistic support. However, more terms reconstructed in proto-Austronesian would relate to crops and domesticated animals than hunting and gathering (Blust 1995), in support of Bellwood's (1997) theory of Austronesian farmers expanding south from Taiwan. If we had to nominate an archaeological corrolary for proto-Makasar, it would be the highly ornate "Sa Huynh-Kalanay" earthenware assemblages in South Sulawesi. These include Ulu Leang 2 in Maros, and the open sites of Kiling-Kiling and Bonto-Bontoa near Bantaeng on the south coast (Ali Fadillah 1999), plus Leang Paja and Batu Ejaya referred to previously. Ulu Leang 2, Leang Paja, and Batu Ejaya clearly group with the c. 3000-year-old Kalumpang site complex, to the immediate northwest of the peninsula, in terms of their repertoire of earthenware decorations (Bulbeck 2000b). But to the northeast of our classical Toalean line, earthenware pottery with even remotely similar decorations has never been reported.

Recent geomorphological work near Lake Tempe by Ian Caldwell and Malcolm Lillie (in press) cannot exclude the possibility of saline intrusions as far inland as the Tempe graben, from both the west and the east, till as recently as 3000 B.P. As this date lies after the point when Austronesians would have first moved into South Sulawesi, according to Bellwood's (1997) theory, early Austronesians could have encountered a virtual island split in two by a major cordillera. Such a situation would have encouraged colonization from two separate seaboards towards the highlands of the cordillera. Regardless of any saline channel, expanding colonists would have found their movements curtailed by the rugged western and southern watershed of the Walanae Valley. Simple environmental determinism would appear to account for the coincidence of lines highlighted in Figure 1, except for one objection. All our available evidence from the Toalean ceramic phase indicates abundant interaction between the Toaleans and whoever brought pottery to the peninsula.

According to Bellwood's theory, the farming capacity of the Austronesian immigrants allowed them to supplant the indigenes whose hunter-gatherer economy severely limited their population density. However, in the South Sulawesi peninsula, farming settlements older than 2000 B.P. are yet to be identified (Bulbeck 1996-97), whereas Toalean sites with a ceramic component abound 
(Table 1). A comparable situation is noted by Glover and Higham (1996:426) for Island Southeast Asia more generally. Far from being in peril of rapid replacement, the Toaleans must have been a dense hunter-gatherer population who evidently tolerated immigrant Austronesian farmers for the benefits they brought. In her analysis of fauna from Leang Burung 1, Simons (1997) observed minimal change bar the appearance of introduced bovid bones in the ceramic layers. In her view, the Toaleans obtained their bovids through exchange with Austronesian farmers, to supplement their dwindling supply of large mammals. Similarly, noting increased variation in use-wear traces on the lithics at Leang Burung 1 after pottery first arrived, Di Lello suggests the Toaleans were now processing a wider variety of plants for purposes of exchange with Austronesian farmers. Alternatively, the Toaleans may have adopted swidden horticulture from their Austronesian neighbors (Di Lello 1997:164). Either exchange with farmers, or a shift by Toaleans towards farming, would best explain the abundant rice in the hearth dated to 960-1860 B.P. at Ulu Leang 1. It is not associated with pottery, as might be expected of an Austronesian hearth, but with typical Toalean debitage and the remains of endemic fauna (Glover $1985: 272$ ).

Immigrant Austronesian farmers would have stood to gain vital knowledge from the indigenous hunter-gatherers. According to linguists, the speakers of "proto-South Sulawesi" could have arrived from the west (Adelaar 1995; Mills 1975; Pelras 1996). If so, they would have reached a land full of unfamiliar fauna and floral regimes (see Whitten et al. 1987). Even if the first farmers arrived to the peninsula via a Sulawesi route, the distribution of wild resources, potable water, and sources of flakeable stone would have been a mystery to them. Without a doubt they would have found themselves using the Toaleans' tracks, acquiring resources and information through exchange, and welcoming Toaleans into their communities. Lithics constitute the hard evidence for this interaction. The projectile points of polished slate observed at Kalumpang are absent from the peninsula. The coastal site of Pakka Mukang, surely an Austronesian settlement, includes two geometric microliths among its assemblage of late Holocene lithics. According to Di Lello (1997), relatively thin and morphologically standardized glossed flakes appeared with the ceramic levels at Leang Burung 1, and these could have been a prototype for the iron "finger knives" used in Island Southeast Asia to harvest rice in ethnographic times.

On reflection, it may not be wise to classify sites of the period as Toalean vs. Austronesian. Our discourse runs into blurred categories-well, as would be expected if immigrant farmers had integrated with the indigenes. We are reminded of the arid debate as to whether the Lamoncong Toale' were really Toalean descendants or Bugis. We can certainly observe continuities between the Toale' and the "ceramic Toaleans," e.g., the use of babirusa (pig deer) tusks as tools or ornaments (Simons 1997:139). The archaeological record for early farmers in the peninsula may be too poor to reflect any absorption of Toalean practices, except in terms of the lithics. However, this archaeological invisibility of the early farmers may itself suggest the Toaleans absorbed the immigrants. Certainly, the Makasar-Bugis distinction in the South Sulawesi peninsula conforms perfectly to a model of early Austronesian colonists mapping onto two discrete, previously established social landscapes. 
The demise of the Maros point, shortly after the introduction of pottery, might be taken to reflect a weakening of the Toaleans' resolve. In her analysis of late Toalean faunal assemblages, Simons (1997) hinted at a shift away from chasing large game, to exchange with neighboring farmers, as the avenue for ambitious individuals to acquire status. The declining status of big-game hunting could account for the loss of the specialized hunter's insignia, the Maros point. However, we propose the introduction of the blowpipe as a more trenchant explanation. Archery does not appear as a traditional skill in South Sulawesi (e.g., Pelras 1996), yet records going back to the sixteenth century refer to guilds specialized in making blowpipes (Bulbeck 1992:108) and regiments of pipe-blowers (Ian Caldwell, pers. comm.). Blowpipes would have replaced the bow (cf. Bellwood 1997:150-151) but not the spear, in accord with the continued manufacture of backed microliths. The demise of the latter can be attributed to the introduction of iron, which was being used to make spearheads in South Sulawesi by 2000 years ago (Bulbeck 2000d). Right across ethnographic Island Southeast Asia, the availability of iron has reduced the ancient skill of flaking stone to hammering strike-a-lights (Bulbeck 2000d; Glover and Ellen 1977; Scheans et al. 1970).

Bellwood (1996) points out that the family trees historical linguists reconstruct from extant languages cannot be explained except via a model of "phylogenetic" diversification. We agree, but add that these trees are derived by systematically excluding all linguistic evidence except that which fits the phylogenetic model. The basic vocabulary of Makasar, for instance, has merely a 38 percent retention rate of cognates from Proto-Malayo-Polynesian (Bellwood 1997:115). That leaves 62 percent of the basic vocabulary open to investigation as borrowings of indigenous, pre-Austronesian terms. The majority of the Makasar lexicon could well stem from horizontal transmission, "reticulation" in Bellwood's (1996) terms, and much of that from terms used by the Toaleans. We make this point simply to allay archaeologists' anxiety in confronting the all-encompassing appearance of historical linguists' trees. Further, the paradigm of idealist culture history employed by historical linguistics (e.g., Blust 1995) ill equips it to gauge reticulate, as opposed to phylogenetic, relationships. Historical linguistics advises us that a major exodus traceable back to Taiwan profoundly shaped Island Southeast Asia in the period 4000-3000 B.P. Our argument has followed that advice, perhaps too slavishly for some readers. But in doing so we have shown that, in the case of South Sulawesi, phylogenetic trees of linguistic diversification miss half the story or more, where we instead need to research the processes of social change and interaction between communities.

\section{ACKNOWLEDGMENTS}

The Waikato (Wk) radiocarbon dates were funded by research grants to Bulbeck from the Department of Anthropology at the University of Western Australia (UWA), and from the Australian Research Council (large grant A59701253). Figures 1, 3, and 4 were prepared by Samantha Coffey of UWA's Photographic Unit, and the artifacts in Figures 2 and 5 were drawn by Adam Freeman of UWA's Center for Archaeology. Figure 6 was drafted by Keith Mitchell of the Australian National University Cartography Unit. 


\section{REFERENCES}

AdelaAR, K. A.

1995 Borneo as a cross-roads for comparative Austronesian linguistics, in The Austronesians: Historical and Comparative Perspectives: 75-95, ed. P. Bellwood, J. J. Fox, and D. Tryon. Canberra: Australian National University.

Ali Fadillah, $M$.

1999 Survei dan ekskavasi Bonto-Bontoa, Bantaeng Timur: Investigasi awal. Walannae 3:13-38.

Ammerman, A. J.

1981 Surveys and archaeological research. Annual Review of Anthropology 10:63-88.

BAHN, P. (ED.)

1992 Collins Dictionary of Archaeology. Glasgow: Harper Collins.

BARTSTRA, G.-J.

1978 Notes on new data concerning the fossil vertebrates and stone tools in the Walanae Valley in South Sulawesi (Celebes). Modern Quaternary Research in Southeast Asia 4:71-72.

1998 Short history of the archaeological exploration of the Maros caves in South Sulawesi. Modern Quaternary Research in Southeast Asia 15:193-210.

Bellwood, P.

1976 Archaeological research in Minahasa and the Talaud Islands, northeastern Indonesia. Asian Perspectives 19(2):240-288.

1985 Holocene flake and blade industries of Wallacea and their predecessor, in Recent Advances in Indo-Pacific Prehistory: 197-205, ed. V. Misra and P. Bellwood. Leiden: E. J. Brill.

1996 Phylogeny vs reticulation in prehistory. Antiquity 70:881-890.

1997 Prehistory of the Indo-Malaysian Archipelago. Rev. ed. Honolulu: University of Hawai'i Press.

Bernadeta, A.K.W.

1998 Wadah kubur Erong di Tanah Toraja, tradisi tekno-religi megalitik. Walannae 2:25-34.

Blust, R.

1995 The prehistory of the Austronesian-speaking peoples: A view from language. Journal of World Prehistory 9:453-510.

Bronson, B., AND T. Asmar

1975 Prehistoric investigations at Tianko Panjang Cave, Sumatra: An interim report. Asian Perspectives $18(2): 128-145$.

Bronson, B., AND I. C. Glover

1984 Archaeological radiocarbon dates from Indonesia: A first list. Indonesia Circle 34:37-44

Bulbeck, F. D.

1989 The Soppeng flaked stone tools and decorated earthenwares, in Survey Pusat Kerajaan Soppeng 1100-1986. Final Report to the Australian Myer Foundation: 97-105, B. Kallupa et al. Canberra: privately published.

1992 A Tale of Two Kingdoms: The Historical Archaeology of Gowa and Tallok, South Sulawesi, Indonesia. Ph.D. diss. Canberra: Australian National University.

1995 Fieldwork in South Sulawesi, 27 December 1994 to 10 January 1995. Report by David Bulbeck to interested parties. Ms. on file.

1996- The Bronze-Iron Age of South Sulawesi, Indonesia: Mortuary traditions, metallurgy and

97 trade, in Ancient Chinese and Southeast Asian Bronze Age Cultures: 1007-1076, ed. F. D. Bulbeck and N. Barnard. Taipei: SMC Publishing, Inc.

$2000 a$ Dental morphology at Gua Cha, West Malaysia, and the implications for "Sundadonty." Bulletin of the Indo-Pacific Prehistory Association 19:17-41.

2000 b Sa Huynh Kalanay revisited: Geographical zonation in western and central MalayoPolynesian decorated pottery. Paper presented at the Fourth Lapita Conference, Australian National University, Canberra, 19-22 June.

$2000 \mathrm{c}$ Sediments and ceramics from Cina and Cenrana. Report to the Australia-Indonesia Institute: Appendix A. Australia-Indonesia Institute, Kingston, ACT.

$2000 d$ The Iron Gates of Indonesia. Two millennia of iron metallurgy in Luwu, South Sulawesi. Paper presented at the Workshop on the Early History of South Sulawesi, Canberra, 1819 August 2000.

Bulbeck, F. D., and B. Prasetyo

1999 The Origins of Complex Society in South Sulawesi (OXIS): Tentative final report to Lembaga Ilmu Pengetahuan Indonesia, Jakarta. 
Caldwell, I., ANd M. Lillie

in press Manuel Pinto's inland sea: Using palaeoenvironmental techniques to assess historical evidence from South Sulawesi. Modern Quaternary Research in Southeast Asia 17.

Chapman, V. C

1981 An Analysis of the Artifact Collections Excavated by the Australian-Indonesian Archaeological Expedition to Sulawesi, 1969, M.A. thesis. Australian National University, Canberra.

1986 Inter-site variability in South Sulawesi: The results of the 1969 Australian-Indonesian Archaeological Expedition. Archaeology in Oceania 21 : 76-84.

Chia, S

1998a Prehistoric pottery production and technology at Bukit Tengkorak, Sabah, Malaysia. Paper presented at the 16th Congress of the Indo-Pacific Prehistory Association, Melaka, Malaysia, 1 to 7 July.

$1998 b$ The obsidian industry at Bukit Tengkorak, Sabah, Malaysia. Paper presented at the 16th Congress of the Indo-Pacific Prehistory Association, Melaka, Malaysia, 1 to 7 July.

Cotterell, B., AND J. Kamminga

1990 Mechanics of Pre-industrial Technology. Cambridge: Cambridge University Press.

DAMMERMAN, K. W.

1939 On prehistoric mammals from South Celebes. Treubia 17:63-72.

Darmawan, M. R., and Albertinus

1991 Gua-Gua Prasejarah di Bantimurung Kabupaten Maros. Ujung Pandang: Suaka Peninggalan Sejarah dan Purbakala Sulawesi Selatan.

Darmawan, M. R., R. IbRahim, and Nusriat

1991 Penelusuran Gua-Gua Prasejarah di Daerah Kabupaten Pangkajene Kepulauan. Ujung Pandang: Suaka Peninggalan Sejarah dan Purbakala Sulawesi Selatan dan Tenggara.

Darmawan, M. R., M. Natsib, S. Sila, and K. Demmanari

1994 Mayat Kering Sulawesi Selatan. Ujung Pandang: Suaka Peninggalan Sejarah dan Purbakala Sulawesi Selatan.

Darmawan, M. R., M. Ramli, and Albertinus

1993 Artefak Epipaleolitik Situs Ralla. Ujung Pandang: Suaka Peninggalan Sejarah dan Purbakala Sulawesi Selatan.

Di Lello, A.

1997 A Use Wear Analysis of Stone Tools from South Sulawesi. Honors diss. University of Western Australia, Perth.

Flavel, A.

1997 Sa-Huhnh Kalanay? Analysis of the Prehistoric Decorated Earthenware of South Sulawesi in an Island Southeast Asian Context. Honors diss. University of Western Australia, Perth.

Flenniken, J. J., AND J. P. White

1985 Australian flaked stone tools: A technological perspective. Records of the Australian Musuem $36: 131-151$.

FORESTIER, $\mathrm{H}$.

1999 L'assemblage industriel de Song Keplek, Java Est. Bulletin de l'École Française d'Extrême Orient $86: 129-159$.

Fox, R. B.

1970 The Tabon Caves. Manila: National Museum.

FRANSSEN, C.J.H.

1949 Bijdrage tot de kennis van het Toaliaan op Zuid-Celebes. Tijdschrift Bataviaansch Genootschap $83: 331-339$.

Glover, I. C.

1976 Ulu Leang cave, Maros: A preliminary sequence of post-Pleistocene cultural developments in South Sulawesi. Archipel 11:113-154.

1978 Survey and excavation in the Maros district, South Sulawesi, Indonesia: The 1975 field season. Bulletin of the Indo-Pacific Prehistory Association 1:60-103.

1979 The effects of sink action on archaeological deposits in caves: An Indonesian example. World Archaeology 10:302-317. 
1985 Some problems relating to the domestication of rice in Asia, in Recent Advances in IndoPacific Prehistory: 265-274, ed. V. Misra and P. Bellwood. Leiden: E. J. Brill.

1986 Archaeology in Eastern Timor, 1966-67. Canberra: Australian National University.

Glover, I. C., AND R. F. Ellen

1977 A further note on flaked stone material from Seram, eastern Indonesia. Asian Perspectives 20(2): 236-240.

Glover, I. C., AND C.F.W. HighaM

1996 New evidence for early rice cultivation in South, Southeast and East Asia, in The Origins and Spread of Agriculture and Pastoralism in Eurasia: 413-441, ed. D. R. Harris. London: UCL Press.

Glover, I. C., and G. Presland

1985 Microliths in Indonesian flaked stone industries, in Recent Advances in Indo-Pacific Prehistory: 185-195, ed. V. Misra and P. Bellwood. Leiden: E. J. Brill.

GREMMEN, W.H.E.

1990 Palynological investigations in the Danau Tempe depression, southwest Sulawesi. Modern Quaternary Research in Southeast Asia 11:123-134.

Grimes, C. E., AND B. D. Grimes

1987 Languages of South Sulawesi. Canberra: Australian National University Pacific Linguistic Series D, No. 78 .

НАкім, В.

1990 Temuan Alat-alat Batu Sisi Timur Sungai Walanae, Mallinrung, Kabupaten Bone. Honors diss. Hasanuddin University, Ujungpandang.

2000 Mata panah bergirigi dari situs Pamangkulang Batua dan Batang Matasapo, Sulawesi Selatan. Walennae $4: 36-41$.

Hiscock, P.

1994 Technological responses to risk in Holocene Australia. Journal of World Prehistory 8:267292.

Hooijer, D. A.

1950 Man and other mammals from Toalian sites in south-western Celebes. Verhandelingen der Koninklijke Nederlandsche Akademie van Wetenschappen, afd. Natuurkunde 46(2):7-160.

JACOB, T.

1967 Some Problems Pertaining to the Racial History of the Indonesian Region. Utrecht: Netherlands Bureau for Technical Assistance.

Keates, S. G., and G.-J. Bartstra

1991- Island migration of early modern Homo sapiens in Southeast Asia: The artifacts from the

92 Walanae Depression, Sulawesi, Indonesia. Palaeohistoria 33-34:19-30.

LIE GoAn LIONG

1965 Palaeoanthropological results of the excavation at the coast of Lewoleba (Isle of Lomblen). Anthropos 60:609-624.

Makkulasse, A. H.

1986 Laporan Pengumpulan Data Peninggalan Sejarah dan Purbakala di Kabupaten Maros. Ujung Pandang: Suaka Peninggalan Sejarah dan Purbakala Sulawesi Selatan.

MCCarthy, F. D.

1940 Comparison of the prehistory of Australia with that of Indo-China, the Malay Peninsula, and the Netherlands East Indies, in Proceedings of the Third Congress of Prehistorians of the Far East: 30-50, ed. F. N. Chasen and M. F. Tweedie. Singapore: Singapore Government Printer.

Mijsberg, W. A.

1941 De anthropologische beteekenis van de Toala's in Zuid-Celebes. Geneeskundig Tijdschrift voor Nederlands-Indië 81:1279-1309.

Mills, R. F.

1975 The reconstruction of proto South Sulawesi. Archipel 10:205-224.

Mithen, S.

1994 The Mesolithic age, in The Oxford Illustrated Prehistory of Europe: 79-135, ed. B. Cunliffe. Oxford: Oxford University Press. 


\section{Mulvaney, D. J., And R. P. Soejono}

1970a Archaeology in Sulawesi, Indonesia. Antiquity 45:26-33.

$1970 b$ The Australian-Indonesian archaeological expedition to Sulawesi. Asian Perspectives 13: 163-177.

Mulvaney, J., And J. Kamminga

1999 Prehistory of Australia. Sydney: Allen and Unwin.

PASQUA, M.

1995 Mid-late Holocene Toalean Sites in South Sulawesi: A Technological Analysis. Honors diss. University of Western Australia, Perth.

Pasqua, M., ANd D. Bulbeck

1998 A technological interpretation of the Toalean, South Sulawesi. Modern Quaternary Research in Southeast Asia $15: 211-232$.

Pelras, C.

1996 The Bugis. London: Blackwell Publishers.

Presland, G.

1980 Continuity in Indonesian lithic traditions. The Artifact 5:19-45.

SARASIN, F.

1906 Die Varietäten des Menschen auf Celebes. Wiesbaden: C. W. Kreidel's Verlag.

Sarasin, P., and F. Sarasin

1905a Die Toála-hoehlen von Lamontjong. Wiesbaden: C. W. Kreidel's Verlag.

19056 Reisen in Celebes. Zweiter Band. Wiesbaden: C. W. Kreidel's Verlag.

Scheans, D. J., K. L. Hutterer, and R. L. Cherry

1970 A newly discovered blade tool industry from the central Philippines. Asian Perspectives $13: 178-181$.

SimANJUNTAK, T.

1994- Kalumpang: hunian sungai bercorak Neolitik-Paleometalik di pedalaman Sulawesi Selatan.

95 Aspek-Aspek Arkeologi Indonesia 17. Jakarta: Pusat Penelitian Arkeologi Nasional.

1995- Cave habitation during the Holocene period in Gunung Sewu. Aspek-Aspek Arkeologi

96 Indonesia 18. Jakarta: Pusat Penelitian Arkeologi Nasional.

Simons, A. G.

1997 The Whole Hog: The Indigenous Response to the Introduction of Farming to South Sulawesi: A Faunal Analysis. Honors diss. University of Western Australia, Perth.

STORM, P.

1995 The Evolutionary Significance of the Wajak Skulls. Scripta Geologica 110. Leiden: Nationaal Natuurhistorisch Museum.

Stuiver, M., G. W. Pearson, and T. Braziunas

1986 Radiocarbon age calibration of marine samples back to $9000 \mathrm{Cal}$ Yr BP. Radiocarbon $28(2 \mathrm{~B}): 805-838$.

Suaka Peninggalan Sejarah dan Purbakala Sulawesi Selatan

1984 Laporan Ekskavasi Penyalamatan Gua Sumpang Bita di Kabupaten Pangkep. Ujung Pandang.

1986 Laporan Pengumpulan Data "Peninggalan Sejarah dan Purbakala" Kabupaten Enrekang. Ujung Pandang.

Subagus, $\mathrm{N}$.

1979 Obsidian industry in Leles, West Java: Preliminary report. Modern Quaternary Research in Southeast Asia 5:35-41.

1986 Alat-alat batu dari Pangkep, Sulawesi Selatan, in Pertemuan Ilmiah Arkeologi IV. I. Manusia, Lingkungan, Hidup dan Teknologi: 246-272. Jakarta: Proyek Penelitian Purbakala Jakarta.

Sukadana, A. A.

1981 Peninggalan manusia di Liang Bua dan hubungannya dengan penemuan di Lewoleba dan Melolo. Berkala Bioantropologi Indonesia $1: 53-72$.

SUMANTRI, I.

1986 Gua Garunggung Sebagai Situs Pemukiman: Suatu Analisis Artefak. Honors diss. Hasanuddin University, Ujung Pandang.

1996 Pola Pemukiman Gua-Gua Prasejarah di Biraeng Pangkep, Sulawesi Selatan. M.A. diss. University of Indonesia, Jakarta. 
Tenazas, R.C.P.

1985 A note on stone and shell implements from late Palaeolithic and Neolithic sites in Caracar, Cebu, Philippines, in Recent Advances in Indo-Pacific Prehistory: 207-209, ed. V. Misra and P. Bellwood. Leiden: E. J. Brill.

VAN DER HoOP, A.N.J. TH. À TH.

1941 Catalogus der Praehistorische Verzameling. Bandung: A. C. Nix and Co.

VAN HEEKEREN, H. R.

1937 Ara, een nieuwe prehistorische vindplaats in Zuid-Celebes. Tijdschrift van het Koninklijk Nederlandsch Aardrijskunding Genootschap 54:30-33.

1939 De Liang Saripa, een neolithisch station nabij Maros (Zuid-Celebes). Tijdschrift voor indische Taal-, Land-en Volkenkunde 79:108-118.

1949 Rapport over de ontgraving te Bola Batoe naar Badjo (Bone, Zuid-Celebes), in Oudheidkundig Verslag 1941-47: 89-107. Bandung: A. C. Nix and Co.

1952 Rock paintings and other prehistoric discoveries near Maros (S. W. Celebes). Laporan Tahunan Dinas Purbakala 1950:22-35.

1957 The Stone Age of Indonesia. The Hague: Martinus Nijhoff.

1972 The Stone Age of Indonesia. 2nd rev. ed. The Hague: Martinus Nijhoff.

Van Stein Callenfels, P. V.

1938a Archaeologisch onderzoek in Celebes. Tijdschrift van het Koninklijk Nederlandsch Aardrijskunding Genootschap $55: 138-142$.

1938 bededeelingen van het Proto-Toalian. Tijdschrift voor indische Taal-, Land-en Volkenkunde $68: 579-584$.

Whitten, A. J., M. Mustafa, And G. S. Henderson

1987 The Ecology of Sulawesi. Yogyakarta: Gadjah Mada University Press.

Williamson, C.

1990 Analysis and Replication of the Flaking Sequence of the Maros Points from Ulu Leang 1. B.A. diss. University of London, London.

\section{ABSTRACT}

This paper reviews the current evidence on typologically specialized tools assigned to the Toalean tradition of the southwest Sulawesi peninsula. Bone points and a range of stone points appeared across the peninsula in the early Holocene; this probably occurred as part of the expansion of archery and improved spear technology in Island Southeast Asia at the time. The technologically most specialized Toalean tools, namely backed microliths and Maros points, were evidently confined to the southwest of the peninsula. Backed microliths occur in contexts spanning some six millennia, but Maros points were largely restricted to the immediately preceramic period, approximately 5500 to 3500 B.P. The distribution of these tool types closely matches the area where late Holocene pottery in the ornate "Sa Huynh-Kalanay" tradition has been recorded, and where Makasar languages are spoken today. Sulawesi's southwest peninsula may have effectively been an island throughout much of the Holocene, and its southwest fringe runs hard against a major cordillera. Thus, physiographic constraints laid the basis for the division of the peninsula into two "social landscapes" that display long-term continuity throughout the Holocene, notwithstanding fundamental changes in subsistence patterns and technology. Keywords: Toalean, South Sulawesi, Makasar, microliths. 